\title{
INSTITUT KESENIAN MAKASSAR
}

\author{
Farul Rizal ${ }^{1}$, St. Aisyah Rahman ${ }^{2}$, Irma Rahayu ${ }^{3}$ \\ Fakultas Sains \& Teknologi UIN Alauddin Makassar \\ E-mail; aisysipala@gmail.com, irmamgee@yahoo.co.id
}

\begin{abstract}
Development of the value of art and culture in Makassar fading, while the higher the education that is expected to help develop arts and cultural preservation. The number of art enthusiasts are having trouble finding a good college and adequate facilities in Makassar divert them out of the area for study. The main purpose of this paper in order to plan and merancangan Art Institute building located in Makassar, which can accommodate the needs of artists to distribute and develop creativity, the result of design art institute building is located in the subdistrict Tamalanrea location is adjusted with the direction of the located area Spatial education, it is expected that the center will be able to accommodate students in distributing and developing creativity and the provision of facilities that can accommodate the development and preservation of local culture and art according to user requirements in accordance with the planning and design standards that apply.
\end{abstract}

Keywords : Institut, art, design.

\footnotetext{
${ }^{1}$ Alumni Jurusan Teknik Arsitektur UIN Alauddin Makassar Angkatan 2008

${ }^{2}$ Dosen Jurusan Teknik Arsitektur UIN Alauddin Makassar

${ }^{3}$ Dosen Jurusan Teknik Arsitektur UIN Alauddin Makassar
} 
Nature

National Academic Journal of Architecture

\section{PENDAHULUAN}

Indonesia kaya akan seni dan budaya. Hal ini disebabkan karena semakin tingginya apresiasi masyarakat dibidang seni. Makassar adalah salah satu kota dengan pengembangan seni yang beragam. Banyak karya seni dihasilkan oleh senimanseniman Makassar, sementara fasilitas untuk menampung kreatifitas seni ini semakin terbatas. Sejumlah akademisi, praktisi seni, dan aparat Pemerintah Provinsi Sulawesi Selatan menyepakati pendirian Institut Seni dan Budaya Indonesia (ISBI) dalam seminar nasional di Makassar. Menurut Sekretaris Provinsi Sulsel Andi Muallim, pihaknya menyediakan lahan seluas 3,5 hektar di Jalan Perintis Kemerdekaan yang tidak jauh dari kampus Universitas Hasanuddin. (http://nasional.kompas.com/diakses18/12/ 2012). Pengembangan nilai seni dan budaya di Makassar semakin luntur, sementara pendidikan tinggi inilah yang diharapkan dapat membantu mengembangkan kelestarian seni dan budaya setempat. Banyak para peminat seni yang kesulitan mencari perguruan tinggi yang baik dan fasilitas yang memadai di Makassar sehingga mereka lebih memilih keluar daerah untuk menuntut ilmu di perguruan tinggi yang lebih memadai. Seperti di ISI Yogyakarta, ISI Surakarta, ISI Bali, Isi Padang Panjang, dan Institut Kesenian Jakarta. Semua universitas itu pun kemungkinan besar memiliki budaya dan kesenian yang berbeda dengan budaya dan kesenian di Makassar. Sudah menjadi hukum alam, bahwa manusia cenderung untuk mendapatkan kesenangan dari kesenian. Namun, hal ini tidak terlepas dari keyakinan agama serta kearifan masingmasing manusia. Setiap keindahan adalah karya seni milik Allah semata, pencipta segala sesuatu. Imbalan untuk keindahan itu, kepada manusia hanya dituntut sikap mensyukuri kepada Allah. Setiap ilmu yang kita dapatkan sangat memiliki berkah jika menyebarkan dan mengamalkannya. Ilmu inilah yang mengangkat derajat kita diantara umat lainnya. Q.S. AlMujadalah/58: 11

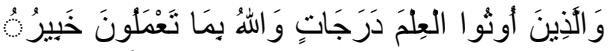

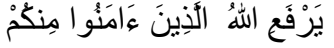

Terjemahnya:

"Allah akan meninggikan orang-orang yang beriman diantara kamu dan orangorang yang diberi ilmu pengetahuan beberapa derajat, Allah mengetahu apa yang kamu kerjakan"

Orang yang beriman dan berilmu pengetahuan akan menunjukkan sikap yang arif dan bijaksana. Iman dan ilmu tersebut akan membuat orang mantap dan agung. Tentu saja yang dimaksud dengan (yang diberi pengetahuan). Ini berarti pada ayat tersebut membagi kaum beriman kepada dua kelompok besar, yang pertama sekedar beriman dan beramal shaleh, dan yang kedua beriman dan bearamal shaleh serta memiliki pengetahuan. Derajat kelompok kedua ini menjadi lebih tinggi, bukan saja karena nilai ilmu yang disandangnya, tetapi juga amal dan pengajarannya kepada pihak lain baik secara lisan, tulisan maupun dengan keteladanan (Shihab, 2002: 79)

Berangkat dari permasalahan diatas, maka muncul gagasan untuk merancang sebuah Institut Kesenian yang berlokasi di Makassar yang dapat mewadahi kebutuhan seniman untuk menyalurkan dan mengembangkan kreativitasnya, serta menghasilkan lulusan yang memiliki kepekaan terhadap nilai-nilai seni dan budaya bangsa, terampil dan kreatif sebagai seniman namun perlu mengetahui bagaimana menyusun suatu acuan perancangan yang dapat menjadi pedoman bagi perencanaan dan perancangan Insitut Kesenian Makassar yang dapat mewadahi Mahasiswa dalam menyalurkan dan mengembangkan kreatifitasnya dan pemberian fasilitas yang dapat mengakomodir pengembangan dan pelestarian seni budaya setempat menurut kebutuhan pengguna dan sesuai dengan 
standar perencanaan dan perancangan yang berlaku.

\section{TINJAUAN PUSTAKA}

Sejarah perguruan tinggi di Indonesia bermula sejak pemerintah Hindia-Belanda memberlakukan politik etis, yang salah satu programnya adalah pendidikan. Program pendidikan mendorong timbulnya sekolah-sekolah yang semula hanya sekolah dasar untuk belajar membaca, menulis, dan menghitung, kemudian diperluas pada sekolah menengah dan perguruan tinggi. Perguruan tinggi ini yang kemudian menjadi cikal bakal berkembangnya universitas dan fakultas di Jakarta, Bandung dan Surabaya.

\section{Dasar Perguruan tinggi}

Pasal 31 Undang-Undang Dasar 1945 Perubahan ke-IV Ayat 1 menyatakan bahwa setiap warga negara berhak mendapatkan pendidikan; Ayat 5 menyatakan bahwa pemerintah memajukan ilmu pengetahuan dan teknologi dengan menjunjung tinggi nilai-nilai agama dan persatuan bangsa untuk kemajuan peradaban serta kesejahteraan umat manusia. Dalam Undang-Undang Republik Indonesia No.12 Tahun 2012 tentang Pendidikan Tinggi yang mengamanatkan kepada pemerintah untuk mengusahakan dan menyelenggarakan satu sistem pendidikan nasional. Tujuan dari pendidikan tinggi menurut UndangUndang No. 12 Tahun 2012 Pasal 5 adalah: Berkembangnya potensi Mahasiswa agar menjadi manusia yang beriman dan bertaqwa kepada Tuhan Yang Maha Esa dan berakhlak mulia, sehat, berilmu, cakap, kreatif, mandiri, terampil, kompeten, dan berbudaya untuk kepentingan bangsa; Dihasilkannya lulusan yang menguasai cabang Ilmu pengetahuan dan/atau Teknologi untuk memenuhi kepentingan nasional dan peningkatan daya saing bangsa; Dihasilkannya Ilmu Pengetahuan dan Teknologi melalui Penelitian yang memperhatikan dan menerapkan nilai Humaniora agar bermanfaat bagi kemajuan bangsa, serta kemajuan peradaban dan kesejahteraan umat manusia; dan terwujudnya Pengabdian kepada Masyarakat berbasis penalaran dan karya Penelitian yang bermanfaat dalam memajukan kehidupan bangsa.

\section{Bentuk Perguruan Institut}

Institut merupakan perguruan tinggi yang menyelenggarakan pendidikan akademik dan dapat menyelenggarakan pendidikan vokasi dalam sejumlah rumpun ilmu pengetahuan dan/atau teknologi teretentu dan jika memenuhi syarat, institut dapat menyelenggarakan pendidikan profesi.

Organisasi institut terdiri atas:

Pimpinan institut, Senat institute, Pelaksana akademik, dan Pelaksana akademik dalam institut yakni Fakultas dengan struktur organisasi terdiri dari: Dekan dan Pembantu Dekan, Fakultas dipimpin oleh Dekan dan dibantu oleh Pembantu Dekan, yang pada dasarnya terdiri atas Pembantu Dekan Bidang Akademik, pembantu dekan bidang Administrasi Umum dan Pembantu Dekan bidang Kemahasiswaan. Senat Fakultas merupakan badan normatif dan perwakilan tertinggi dilingkungan fakultas yang memiliki wewenang untuk menjabarkan kebijakan dan peraturan institut untuk fakultas yang bersangkutan. Pelaksana Akademik dalam fakultas adalah sebagai berikut: Jurusan, Laboratorium / Studio, Ketua jurusan, Lembaga penelitian

Pelaksana administrasi (Biro), terdiri atas : Biro adamistrasi akademik, Biro administrasi keuangan, Biro administrasi umum, Biro administrasi kemahasiswaan, Biro administrasi perencanaan dan sistem informasi. Unit pelaksana Teknis, harus memiliki perpustakaan, pusat komputer, laboratorium/studio, dan unsur penunjang lainnya yang diperlukan untuk penyelenggaraan perguruan tinggi. 


\section{Defenisi Seni}

Aristoteles mengemukakan bahwa, seni adalah kemampuan membuat sesuatu dalam hubungannya dengan upaya mencapai suatu tujuan yang telah ditentukan oleh gagasan tertentu, demikian juga dikemukakan oleh sastrawan Rusia terkemuka Leo Tolstoy mengatakan bahwa, seni merupakan kegiatan sadar manusia dengan perantaraan (medium) tertentu untuk menyampaikan perasaan kepada orang lain. Menurut Ki Hajar Dewantara seni adalah keindahan, menurutnya seni adalah segala perbuatan manusia yang timbul dan hidup perasaannya dan bersifat indah hingga dapat menggerakkan jiwa perasaan manusia lainnya, selanjutnya dikatakan oleh Akhdiat K. Mahardja; seni adalah kegiatan manusia yang merefleksikan kenyataan dalam suatu karya, yang berkat bentuk dan isinya mempunyai daya untuk membangkitkan pengalaman tertentu dalam alam rohani si penerimanya. Ungkapan seni menurut Erich kahler, seni adalah suatu kegiatan manusia yang menjelajahi, menciptakan realitas itu dengan simbol atau kiasan tentang keutuhan 'dunia kecil' yang mencerminkan 'dunia besar'. (Arini, 2008).

\section{Fungsi Seni}

Arini dalam bukunya Seni Budaya Jilid 1(2008) menyatakan bahwa fungsi seni terdiri atas; fungsi ritual, fungsi pendidikan,

fungsi komunikasi, Fungsi hiburan, fungsi artistik, Fungsi guna (seni terapan), Fungsi seni untuk kesehatan (terapi).

\section{Klasifikasi Seni}

Klasifikasi seni dikelompokkan atas; Seni rupa murni banyak ditemukan pada cabang seni grafika, seni lukis, dan seni patung.

Seni rupa terapan adalah seni rupa yang memiliki nilai kegunaan (fungsional) sekaligus memiliki nilai seni, bertujuan untuk memenuhi kebutuhan praktis atau memenuhi kebutuhan sehari-hari secara materi, misalnya furnitur, tekstil, dan keramik. Seni Desain mengalami perluasan makna, yaitu sebagai kegiatan manusia yang berupaya untuk memecahkan masalah kebutuhan fisik. Desain merupakan suatu aktivitas yang bertitik tolak dari unsur-unsur obyektif dalam mengekspresikan gagasan visualnya.Seni Kriya Perkembangan dalam dunia seni rupa, adalah munculnya kriya sebagai bagian tersendiri yang terpisah dari seni rupa murni. Kriya merupakan pengindonesiaan dari istilah Inggris Craft, yaitu kemahiran membuat produk yang bernilai artistik dengan keterampilan tangan, produk yang dihasilkan umumnya eksklusif dan dibuat tunggal, baik atas pesanan ataupun kegiatan kreatif individual.

\section{Seni Pertunjukan}

Dalam http: //id.wikipedia.org/wiki/Seni pertunjukan, diakses tanggal 24/09/2012, Seni pertunjukan (Bahasa Inggris: performance art) adalah karya seni yang melibatkan aksi individu atau kelompok di tempat dan waktu tertentu. Performance biasanya melibatkan empat unsur: waktu, ruang, tubuh si seniman dan hubungan seniman dengan penonton. Klasifikasi seni pertunjukan adalah sebagai berikut:

Seni Musik, Seni Teater, Seni tari, Seni kerajinan tangan, Seni ukir, Anyaman, tenun, dll.

\section{Studi Banding \\ Institut Seni Indonesia Yogyakarta (ISI Yogyakarta)}

Institut Seni Indonesia Yogyakrata atau dikenal dengan ISI Jogja adalah sebuah lembaga pendidikan tinggi seni negeri yang berstatus perguruan tinggi penuh, dan memiliki kewenangan untuk menyelenggarakan pendidikan sampai ke jenjang tertinggi dan merupakan perguruan tinggi seni terbesar \& terbaik di Indonesia. 


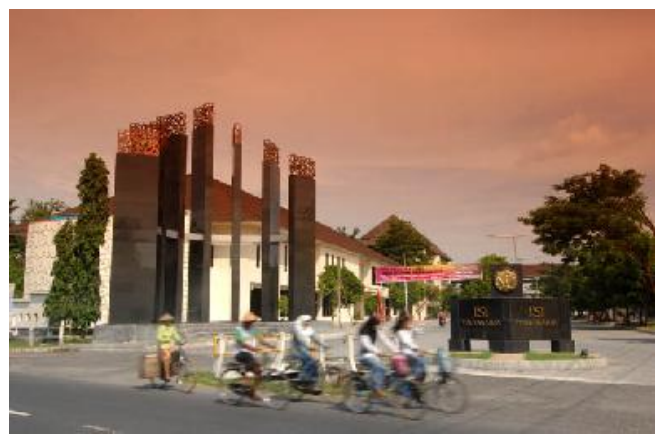

Gambar II.33 Gapura Institut Seni Indonesia Yogyakarta

(Sumber: http://isi.ac.id/profil/ diakses 02/10/2012)

\section{Lokasi}

Institut Seni Indonesia Yogyakarta atau yang disingkat ISI Yogyakarta adalah sebuah perguruan tinggi seni negeri yang terdapat di Kota Yogyakarta, Indonesia. Tepatnya di Jl. Parangtritis Km. 6, kelurahan desa Panggungharjo, kecamatan Sewon, kabupaten Kabupaten Bantul, Daerah Istimewa Yogyakarta. Kampus ISI Jogja berada diatas tanah seluas 18 hektar yang berlokasi di Panggungharjo, Sewon, Bantul - lingkungan pedesaan yang masih hijau, asri dengan udara yang masih segar. eskipun di lingkungan pedesaan namun mudah dijumpai toko-toko alat tulis dan fotokopi, pasar swalayan, warung makan. Serta rumah-rumah kost dengan biaya murah. Kondisi ini sangat menguntungkan bagi mahasiswa dalam kehidupannya, belajar dan berkarya. Lahan dipenuhi dengan vegetasi-vegetasi yang dapat menyejukkan serta mereda kebisingan sekitar kampus. Kelebihan ISI Yogyakarta ini adalah adalanya keseragaman bentuk antar bangunan-bangunan didalamnya. Pola sirkulasi juga jelas dan menggunakan vegetasi-vegetasi yang dapat menyejukkan kampus. Material-material seperti kaca bening untuk memasukkan pencahayaan alami kedalam bangunan juga merupakan kelebihan kampus ISI Yogyakarta.

\section{School of Art Design and Media (Singapura)}

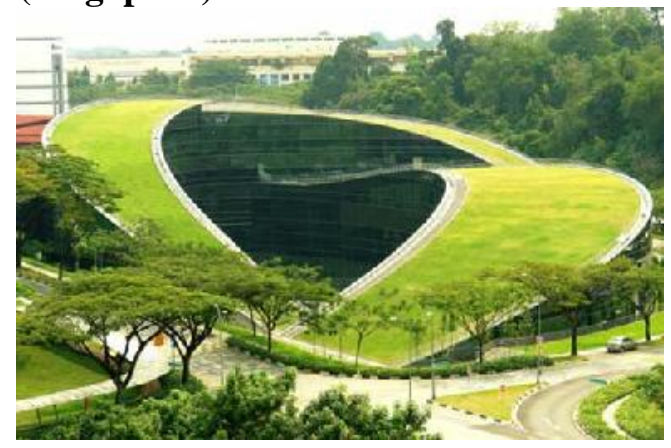

Gambar II. 47.School Of Art Design \& Media di Singapura ( sumber :

http://www.architecturelist.com, diakses 10Oktober 2012 )

\section{Lokasi}

School of art design \& Media terletak di Jalan Nanyang Ave (http: //en.wikipedia. org , diakses 10 Oktober 2012), yang berada dalam kawasan Kampus NTU ( Nanyang Technology University ). Disain bangunan ini dibuat berkonsep menyatu dengan lingkungan, terdiri dari 3 blok yang terjalin dengan atap hijau yang muncul sebagai perluasan alami dari tanah. Facade kaca pada bangunan menggunakan warna abu-abu netral cara ini dapat mengurangi beban panas matahari dengan tetap memberi pandangan alami dan cahaya matahari ke dalam ruang. Dinding kaca memberikan pertukaran visual, memungkinkan siswa dan guru untuk menikmati pemandangan sekitarnya. Cahaya matahari berlimpah disebarkan di seluruh studio dan ruang kelas, disaring melalui dedaunan sekitarnya yang melengkung menjadi pembeda dari struktur lain di kampus dengan garis antara lanskap dan bangunan yang abstrak. Atap berfungsi sebagai ruang pertemuan informal yang menciptakan ruang terbuka, melindungi bangunan, mendinginkan udara sekitarnya dan proses daur ulang air hujan untuk irigasi lansekap. Rancangan fasad menggunakan sistem tirai dinding kaca mengkilat dengan warna abu-abu netral. 
Bagian sisa bangunan terdiri dari dinding beton, cara ini ini untuk menjaga integritas desain dan kealamian.

\section{Interior}

Pintu masuk ganda mengarah ke sebuah lobby besar dengan elemen sirkulasi, yaitu lift, tangga terbuka dan jembatan. Dari ruang lobi dapat dengan cepat mengakses ke bagian lain dari bangunan.

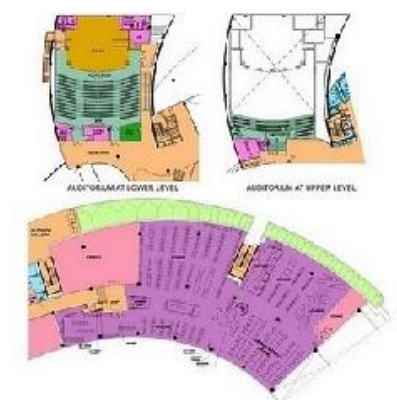

Gambar II.53Konsep ruang dalam (Sumber: http://www.designshare.com, diakases 10 Oktober 2012)

\section{Material}

Bahan material bangunan menggunakan beton bertulang, terlihat pada penggunaan sistem rangka kaku yang digunakan. Secara arsitektur, misalnya pada sistem fasade, bangunan ini menggunakan sistem tirai kaca atau curtain wall, untuk menurunkan suhu udara dalam ruang, atap yang melengkung dirancang memanfaatkan tanaman rumput. Pemanfaatan tanaman rumput ini secara signifikan dapat menurunkan suhu dalam ruangan, sehingga penggunaan sistem AC dapat diminimalkan. Gedung ini memiliki banyak kelebihan daintaranya; memiliki bentuk yang unik dan menyatu dengan lingkungan, Penggunaan material yang hemat energy, memiliki green roof yang dapat mengurangi panas pada bangunan, merupakan bangunan dengan konsep arsitektur hijau.

\section{METODELOGI PENULISAN}

Metode yang digunakan dalam penelitian ini adalah metode penelitian kualitatif dengan mengaplikasikan langsung dalam konsep desain perancangan. Teknik pengambilan data dilakukan dengan survey lapangan melihat fakta yang ada di lapangan dan dianalisis dalam bentuk konsep desain untuk menghasilkan desain perancangan yang sesuai. Selain itu teknik pengambilan data juga dilakukan dengan wawacara langsung dan selanjutnya diolah untuk kemungkinan peruntukan desain yang tepat di dalam kawasan tersebut. Study literature juga digunakan disini untuk memberikan masukan berupa teoriteori pendekatan desain sebuah gedung kesenian.

\section{HASIL PEMBAHASAN}

\section{PENDEKATAN DESAIN \\ Tapak, tata Lingkungan dan kondisi lingkungannya.}

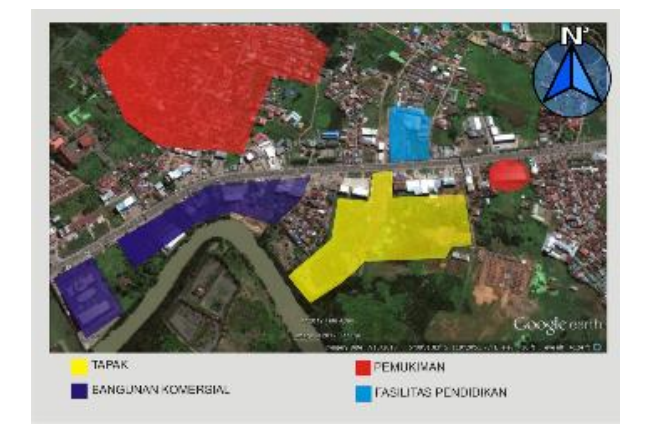

Gambar IV.1 Kondisi lingkungan sekitar Tapak (Sumber: Http://www.googlearth.com , modifikasi, 2012)

Lokasi dipilih di Kecamatan Tamalanrea, tepatnya Jalan Perintis Kemerdekaan yang digunakan untuk fungsi komersial, pemukiman dan pendidikan tinggi. Beberapa fasilitas komersil yang terdapat disekitar tapak adalah Mall Makassar Town Square, ruko-ruko, showroom mobil, swalayan dan rumah makan. Fasilitas pendidikan yang ada disekitar tapak adalah STIMIK Dipanegara dan Universitas Hasanuddin. Kawasan yang merupakan pusat pengembangan ekonomi ini terdapat berbagai fasilitas komersil bertebaran di sekitaran Jalan Perintis 
Kemerdekaan. Hal ini merupakan karakter kuat lokasi ini untuk pembangunan Institut Kesenian Makassar.

\section{Potensi dan Kendala Tapak}

Potensi-potensi yang ada pada tapak; lokasi yang mudah dicapai oleh konsumen dengan kendaraan umum atau pribadi. Keadaaan lingkungan yang sesuai dengan perencanaan Institut Kesenian Makassar karena dekat dengan perguruan tinggi lainnya seperti Universitas Hasanuddin dan STIMIK Dipanegara. Lokasi dijangkau oleh utilitas kota, khususnya air bersih dan jaringan listrik. Kondisi topografi dan ruang yang memadai, memiliki dimensi lahan yang memadai untuk perencanaan. Adapun yang menjadi kendala pada tapak adalah kemacetan yang sering terjadi di Jl. Perintis kemerdekaan, diperlukan penimbunan pada tapak untuk pembangunan Institut Kesenian Makassar, karena tapak sebahagian memiliki rawa.

\section{Ukuran dan Tata Wilayah (Dimensi Tapak)}

Luas lahan pada tapak sebesar \pm 40.000 m2. Tapak ini diharapkan memiliki luas lahan yang memadai untuk pembangunan Institut Kesenian Makassar yang memiliki fasilitas gedung rektorat, 3 buah fakultas, masjid, perpustakaan, gedung pameran dan pertunjukan, lapangan olahraga, kantin dan fasilitas servis

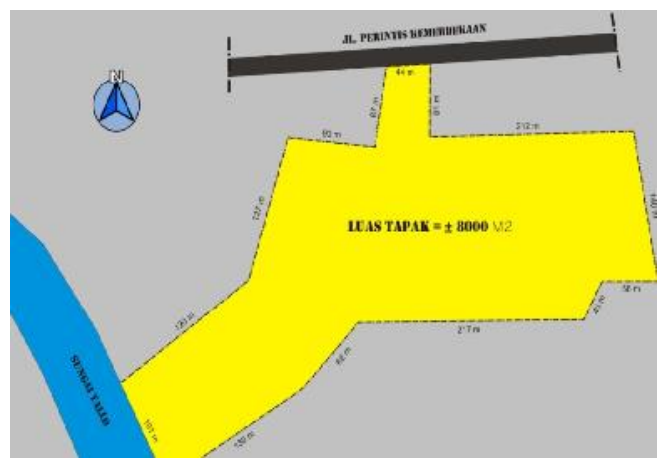

Gambar IV.2 Dimensi tapak (Sumber: Analisa Penulis, 2012)

\section{Batas Tapak}

Lokasi perencanaan terletak di Kecamatan Tamalanrea, terletak antara $119^{\circ} 28^{\prime} 56^{\prime} 93^{\prime \prime}$ Bujur Timur dan $5^{\circ} 8^{\prime} 30^{\prime} 61^{\prime \prime}$ Lintang Selatan yang berbatasan sebelah utara dengan Jl.Perintis Kemerdekaan, sebelah timur dengan ruko dan pemukian, sebelah selatan dengan Lahan kosong dan sebelah barat adalah ruko dan pemukiman. Jl. Perintis kemerdekaan sebagai batas sebelah utara digunakan sebagai sirkulasi menuju tapak.

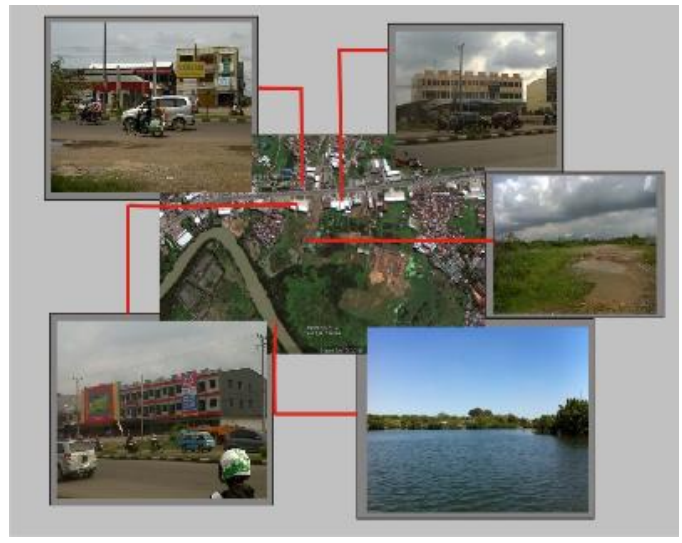

Gambar IV.3 Batas Tapak (Sumber: Analisa Penulis, 2012)

Perumahan-perumahan yang berada di sebelah timur maupun barat sedemikian mungkin tidak terganggu kenyamanannya. Desain IKM akan lebih dikembangkan keindahannya dengan adanya Sungai Tallo di sebelah selatan tapak. Untuk lahan kosong yang juga berada di sisi selatan diharapkan dapat menjadi lahan pengembangan IKM nantinya.

\section{Analisis Tapak Sempadan}

Analisis sempadan yang ada pada tapak diuraikan pada tabel berikut ini berdasarkan kondisinya: 
Tabel IV.1. Analisis Sempadan

\begin{tabular}{|c|c|}
\hline \multirow[t]{2}{*}{ Kondisi } & \\
\hline & $\begin{array}{l}\text { Garis Sempadan Jl. Perintis } \\
\text { kemerdekaan }=20 \mathrm{~m} \\
\text { Garis sempadan sungai Tallo }= \\
25 \mathrm{~m} \\
\text { Koefisien Lantai Bangunan }=40 \% \\
\text { dari tapak }\end{array}$ \\
\hline \multirow[t]{2}{*}{$\begin{array}{l}\text { Hasil } \\
\text { Analisis }\end{array}$} & . \\
\hline & $\begin{array}{l}\text { Tidak melakukan pembangunan } \\
\text { gedung pada garis sempadan yang } \\
\text { telah ditentukan, baik sempadan } \\
\text { jalan maupun sempadan sungai } \\
\\
\text { Perbandingan BC adalah } 30 \%: 70 \\
\% \text {, jumlah terbangun sebesar } 30 \% \\
\text { sedangkan yang tidak } \\
\text { terbangun70\% }\end{array}$ \\
\hline
\end{tabular}

Sumber: Analisis penulis, 2012

\section{Keistimewaan Fisik Alamiah}

Analisis keistimewaan fisik alami yang ada pada tapak diuraikan pada tabel berikut ini: Tabel IV.2 Analisis keistimewaan Alamiah pada tapak

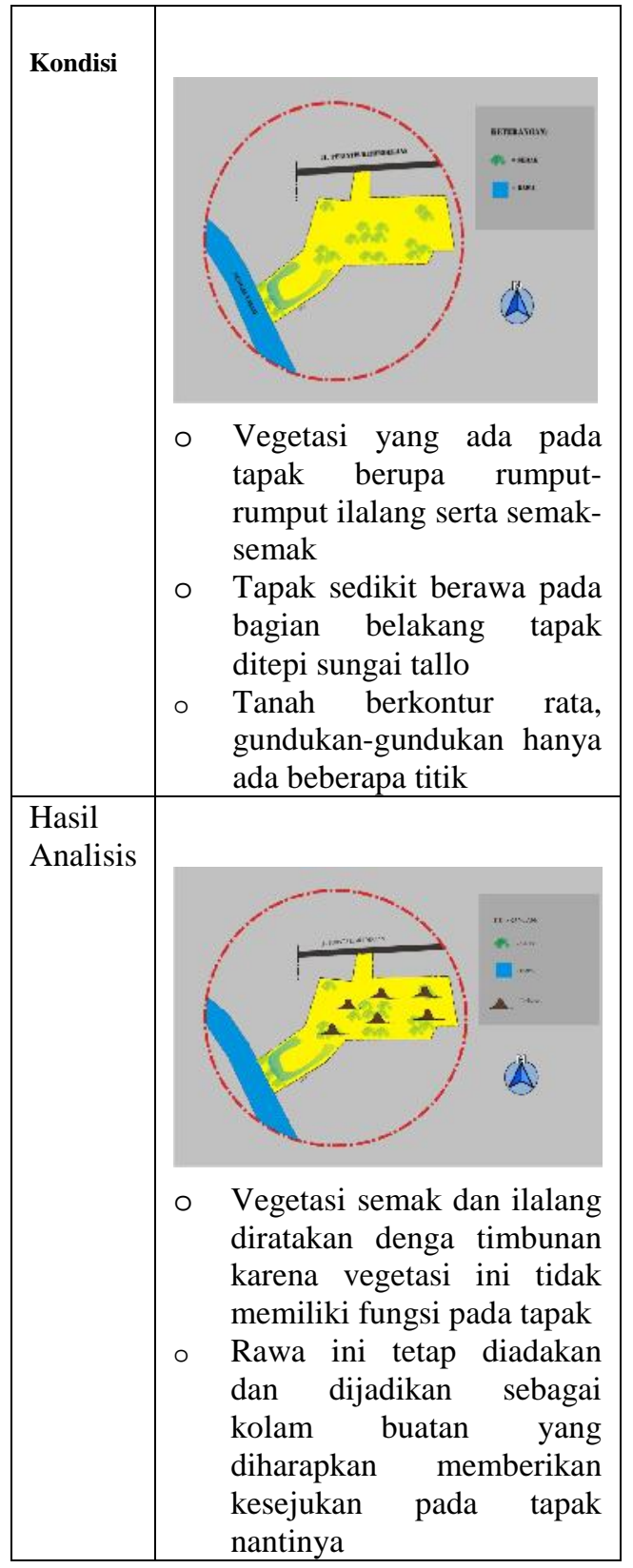

Sumber: Analisis penulis, 2012 
Nature

\section{Sirkulasi}

Analisis sirkulasi menuju pada tapak diuraikan pada tabel berikut ini:

Tabel IV.3 Analisis Sirkulasi menuju tapak

\begin{tabular}{|c|c|}
\hline Kondisi & $\begin{array}{l}\text { J1. Perintis kemerdekaan adalah } \\
\text { salah satu alternatif menuju tapak. }\end{array}$ \\
\hline $\begin{array}{l}\text { Hasil } \\
\text { Analisis }\end{array}$ & $\begin{array}{l}\text { Mobil, motor dan pejalan kaki } \\
\text { masuk menuju tapak melalui } \\
\text { jalan perintis kemerdekaan } \\
\text { Tempat parkir diletakkan dekat jl } \\
\text { perintis agar mudah mengatur } \\
\text { sirkulasi menuju tapak }\end{array}$ \\
\hline
\end{tabular}

Sumber: Analisis penulis, 2012

\section{Utilitas}

Analisis utilitas yang disediakan disekitar tapak diuraikan pada tabel berikut ini:

Tabel IV.4 Analisis Utilitas yang dilalui oleh tapak

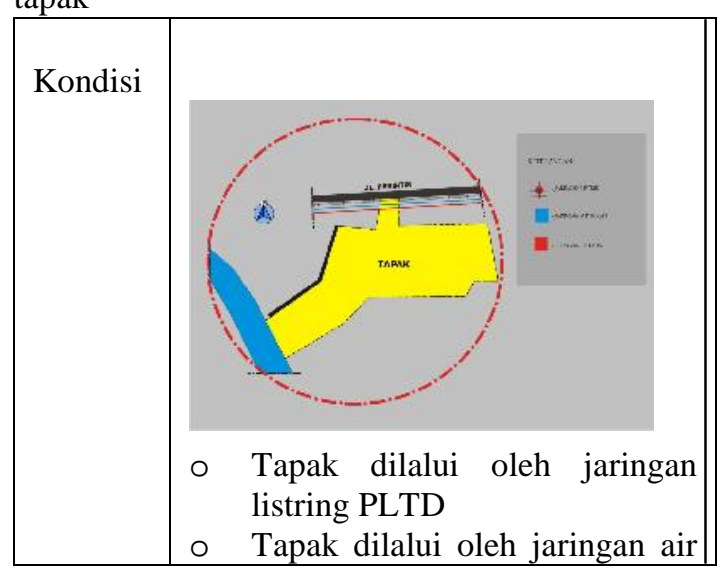

\begin{tabular}{|l|l|l|}
\hline & $\begin{array}{l}\text { bersih PAM } \\
\text { Tapak dilalui oleh jaringan } \\
\text { telepon PT.TELKOM }\end{array}$ \\
\hline Hasil & & \\
Analisis & & $\begin{array}{l}\text { Jaringan Listrik PLTD } \\
\text { didistribusikan menuju tapak } \\
\text { Jaringan air bersih PAM } \\
\text { didistribusikan menuju tapak } \\
\text { Jaringan Telepon PT.TELKOM } \\
\text { didistribusikan menuju tapak }\end{array}$ \\
\hline
\end{tabular}

Sumber: Analisis penulis, 2012 
Nature

National Academic Journal of Architecture

\section{Panca Indra (View)}

Analisis View pada tapak diuraikan pada tabel berikut ini:

Tabel IV.5 Analisis View /pemandangan dari tapak

\begin{tabular}{|c|c|}
\hline Kondisi & $\begin{array}{l}\text { View dari/ke utara adalah view } \\
\text { dar/ke jalan perintis } \\
\text { kemerdekaan } \\
\text { OView dari/ke timur adalah view } \\
\text { dari/ke lahan kosong dan } \\
\text { beberapa rumah } \\
\text { O View dari/ke selatan adalah } \\
\text { view dari/ke sungai dan lahan } \\
\text { kosong } \\
\text { OView dari/ke barat adalah view } \\
\text { dari/ke perumahan }\end{array}$ \\
\hline $\begin{array}{l}\text { Hasil } \\
\text { Analisis }\end{array}$ & $\begin{array}{l}\text { view terbaik adalah view } \\
\text { menghadap jalan Perintis } \\
\text { kemerdekaan } \\
\text { Catching Point dari arah } \\
\text { Jalan Perintis Kemerdekaan } \\
\text { Gerbang diletakkan pada } \\
\text { view yang terbaik }\end{array}$ \\
\hline
\end{tabular}

Sumber: Analisis penulis, 2012

\section{Kebisingan}

Analisis kebisingan menuju tapak diuraikan pada tabel berikut ini:

Tabel IV.6 Analisis kebisingan pada tapak dan disekitarnya

\begin{tabular}{|c|c|}
\hline Kondisi & $\begin{array}{l}\text { O Kebisingan tertinggi } \\
\text { bersumber dari suara } \\
\text { kendaraan dan orang-orang } \\
\text { dari arah Jl. Perintis } \\
\text { Kemerdekaan } \\
\text { Kebisingan } \\
\text { bersumber dari kawasan } \\
\text { perumahan di sisi barat } \\
\text { tapak } \\
\text { Sedangkan disisi selatan } \\
\text { dan timur tapak hamper } \\
\text { tidak ada kebisingan, } \\
\text { karena hanya beberapa } \\
\text { rumah yang ada dan hanya } \\
\text { terdapat lahan kosong. }\end{array}$ \\
\hline \multirow[t]{2}{*}{$\begin{array}{l}\text { Hasil } \\
\text { Analisis }\end{array}$} & \\
\hline & $\begin{array}{l}\text { Pohon digunakan sebagai } \\
\text { barrier untuk meminimalisir } \\
\text { kebisingan menuju tapak } \\
\text { Oeninggikan level juga } \\
\begin{array}{ll}\text { dapat } & \text { mengurangi } \\
\text { kebisingan } & \end{array}\end{array}$ \\
\hline
\end{tabular}

Sumber: Analisis penulis, 2012 
Nature

National Academic Journal of Architecture

Iklim

Analisis iklim pada tapak diuraikan pada tabel berikut ini:

Tabel IV.7 Analisis iklim pada tapak

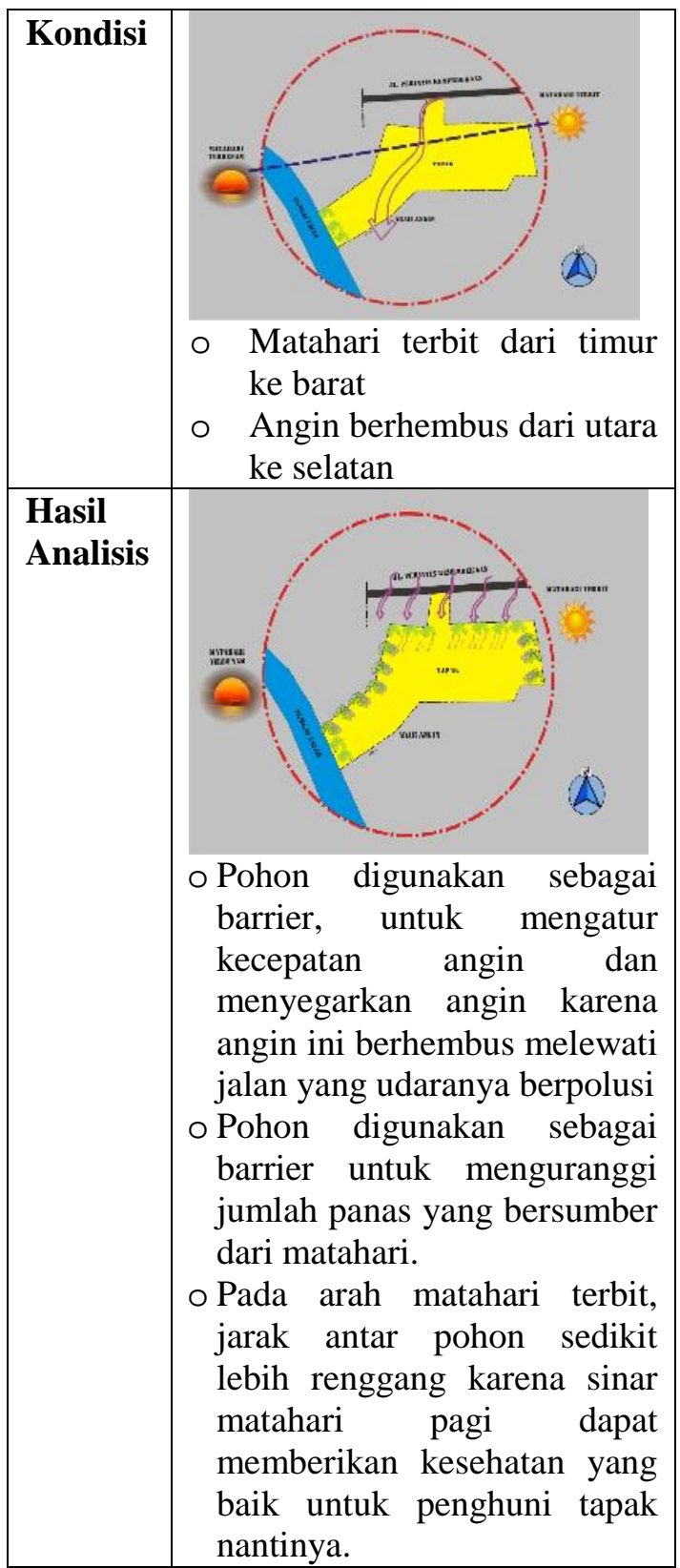

\section{Bentuk Dasar}

Alternatif pemilihan bentuk dasar Institut Kesenian Makassar adalah sebagai berikut:

Tabel IV.8 Analisis bentuk dasar bangunan IKM

\begin{tabular}{|c|c|c|c|}
\hline $\begin{array}{l}\text { Bentuk } \\
\text { Dasar }\end{array}$ & Kelebihan & $\begin{array}{c}\text { Kekuran } \\
\text { gan }\end{array}$ & Hasil Analisis \\
\hline $\begin{array}{l}\text { Segi } \\
\text { Empa } \\
\text { t }\end{array}$ & $\begin{array}{l}\text { Formal } \\
\text { Bersifat } \\
\text { murni dan } \\
\text { rasional } \\
\text { Memiliki } \\
\text { arah yang } \\
\text { tertentu }\end{array}$ & $\begin{array}{l}\text { Bentuk } \\
\text { yang } \\
\text { kurang } \\
\text { menarik } \\
\text { dan } \\
\text { rekreatif }\end{array}$ & $\begin{array}{l}\text { Mudah dalam penataan } \\
\text { ruang } \\
\text { Bagunan akan terkesan } \\
\text { formal dan sesuai } \\
\text { dengan fungsinya yaitu } \\
\text { pendidikan tinggi }\end{array}$ \\
\hline $\begin{array}{l}\text { Lingk } \\
\text { aran }\end{array}$ & $\begin{array}{l}\text { Bersifat } \\
\text { stabil } \\
\text { Terpusat } \\
\text { Tenang } \\
\text { Rekreatif }\end{array}$ & informal & $\begin{array}{l}\text { Bangunan terlihat akan } \\
\text { tenang dan rekreatif } \\
\text { kurang cocok dengan } \\
\text { fungsi IKM }\end{array}$ \\
\hline $\begin{array}{l}\text { Segiti } \\
\text { ga }\end{array}$ & $\begin{array}{l}\text { Stabil } \\
\text { Seimbang } \\
\text { Terpusat }\end{array}$ & informal & $\begin{array}{l}\text { Bangunan IKM tidak } \\
\text { terlihat begitu formal } \\
\text { dan pembagian ruang } \\
\text { yang rumit serta } \\
\text { susahnya penataan } \\
\text { perabot. }\end{array}$ \\
\hline $\begin{array}{l}\text { Gabu } \\
\text { ngan } \\
\text { Segie } \\
\text { mpat } \\
\text { dan } \\
\text { lingka } \\
\text { ran }\end{array}$ & $\begin{array}{l}\text { Formal } \\
\text { Stabil } \\
\text { Terpusat } \\
\text { Rekreatif } \\
\text { Tenang }\end{array}$ & - & $\begin{array}{l}\text { Bangunan IKM akan } \\
\text { terkesan lebih formal } \\
\text { dan tenang serta } \\
\text { rekreatif }\end{array}$ \\
\hline $\begin{array}{l}\text { Gabu } \\
\text { ngan } \\
\text { Segie } \\
\text { mpat } \\
\text { denga } \\
\text { n } \\
\text { Segiti } \\
\text { ga }\end{array}$ & $\begin{array}{l}\text { Formal } \\
\text { Stabil } \\
\text { Terpusat }\end{array}$ & $\begin{array}{l}\text { Bentuk } \\
\text { tidak } \\
\text { tenang } \\
\text { dan } \\
\text { rekreatif }\end{array}$ & $\begin{array}{l}\text { Bangunan IKM terkesan } \\
\text { formal terpusat tetapi } \\
\text { tidak rekreatif serta } \\
\text { penataan perabot yang } \\
\text { rumit }\end{array}$ \\
\hline $\begin{array}{l}\text { Gabu } \\
\text { ngan } \\
\text { Lingk } \\
\text { aran } \\
\text { denga } \\
\text { n } \\
\text { segiti } \\
\text { ga }\end{array}$ & $\begin{array}{l}\text { Terpusat } \\
\text { Stabil } \\
\text { Tenang } \\
\text { Rekreatif }\end{array}$ & Informal & $\begin{array}{l}\text { Bangunan terkesan tidak } \\
\text { formal. }\end{array}$ \\
\hline
\end{tabular}

Sumber: Analisa Penulis (2012)

Sumber : Analisa, 2012 


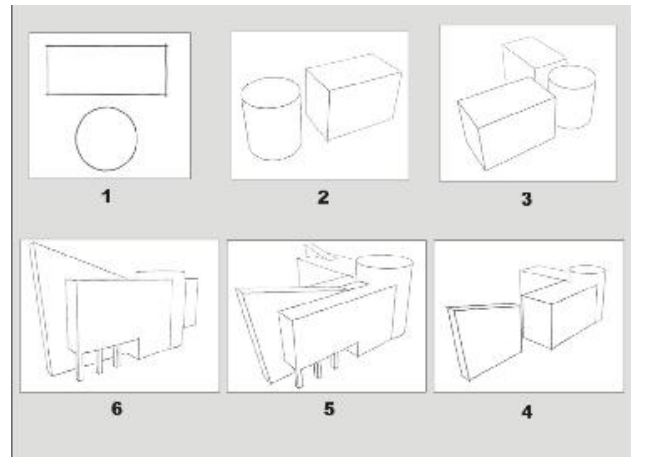

Gambar IV.4 Sketsa Transformasi Bentuk Fasade IKM, (Sumber:Dokumen Pribadi, 2013)

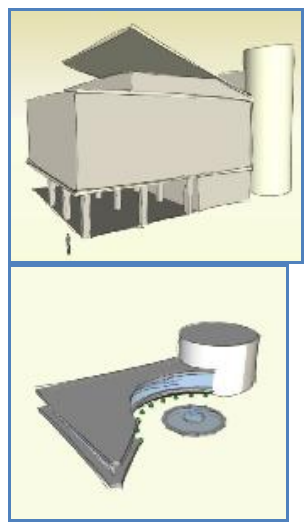

Gambar IV.5 Bentuk lain yang tercipta dari bentuk dasar persegi dan lingkaran (Sumber:Dokumen Pribadi, 2013)

Bentuk dan penampilan bangunan yang diterapkan pada desain IKM adalah sebagai berikut:

\section{Bentuk yang fungsional}

Bentuk bangunan yang digunakan pada perancanaan IKM adalah gabungan segiempat dan lingkaran. Penggabungan ini memberikan kesan formal dan rekreatif sesuai dengan kegiatan-kegiatan yang berlangsung didalamnya.

\section{Penyesuaian terhadap iklim}

Penyelesaian tersebut seperti bentuk bukaan, pemanfaatan cahaya matahari dan penghawaan alami, serta pemanfaatan teritisan yang dapat mengurangi panas matahari, serta air hujan.

\section{Material}

Penggunaan material tertentu seperti ACP (Aluminium Composite Panel) dan kaca memberikan kesan bangunan bergaya modern.

\section{Irama}

Kesesuaian bentuk antara bangunan yang satu dengan bangunan yang lainnya. Kesesuaian warna juga harus diterapkan antara unit bangunan.

\section{A.}

\section{B. Struktur}

Bangunan Institut Kesenian Makassar merupakan bangunan multi massa yang setiap massanya bukan merupakan bentang lebar maupun berlantai banyak. Penerapan strukturnya berupa pondasi, kolom, balok dan rangka atap yang menyesuaikan bentuk bangunan. Sistem struktur bangunan pada tiap massa bangunan pada Institut Kesenian Makassar menggunakan sistem struktur rangka, dimana bangunan dibentuk dengan rangka berupa kolom dan balok serta pondasi. Berdasarkan Analisis jenis- jenis pondasi maka pondasi yang digunakan untuk Institut Kesenian Makassar memenuhi 3 syarat sebagai berikut:

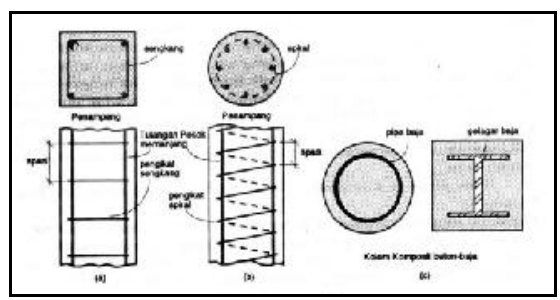

Gambar IV.9 Jenis-jenis kolom (Sumber:http://tekniksipilinfo.blogspot.com/20 11/09/jenis-jenis-kolom-beton.html, diakses 18/12/2012)

Pondasi harus aman terhadap kegagalan struktural yang dapat mengakibatkan keruntuhan.Pondasi tidak boleh menurun selama umur bangunan yang demikian Pondasi harus layak dari segi teknis, ekonomis, serta praktis untuk dibangun tanpa pengaruh buruk terhadap bangunan sekitar. 
Nature

National Academic Journal of Architecture

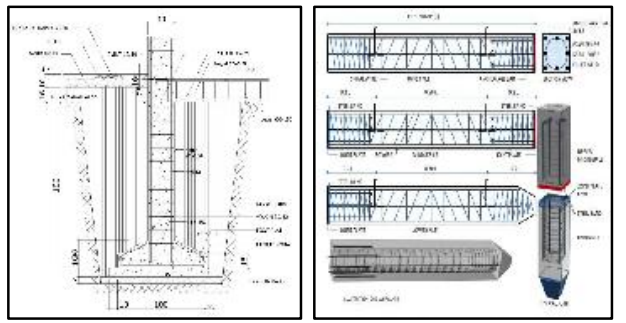

Gambar IV.6 Jenis pondasi telapak dan pondasi rakit

(Sumber:http://atadroe88.blogspot.com/jenis-jenispondasi.htmldiakses tanggal 8/12/2012)

Plat lantai adalah lantai yang terletak diatas tanah langsung, jadi merupakan lantai tingkat. Fungsi plat lantai adalah sebagai berikut (Dipohusodo, 1994); memisahkan ruang bawah dan ruang atas sebagai tempat berpijak penghuni di lantai tingkat, menempatkan kabel listrik dan lampu pada ruang bawah, meredam suara dari ruang atas maupun ruang bawah, menambah kekuatan bangunan pada arah horizontal, plat lantai yang digunakan pada banguan IKM adalah plat lantai beton yang disesuaikan dengan struktur kolom dan balok. Plat lantai beton ini memiliki keuntungan yaitu kuat dan lebih ekonomis.

\section{Struktur Atap}

Struktur atap berfungsi sebagai menyalurkan beban pada atap dan material penutup atap. Selain itu, atap juga merupakan pelindung bangunan dari panas, dingin, hujan.

\section{Material}

Material dinding merupakan hal yang harus diperhatikan pada bangunan bermassa seperti IKM. Material dinding yang diharapkan disamping ekonomis juga memiliki ketahanan yang baik. Pemilihan material yang sesuai untuk IKM dijelaskan sebagai berikut; Bata ringan yang dikenal dengan hebel atau celcon merupakan hasil campuran dari pasir kwarsa, semen, kapur, sedikit gypsum, air, dan aluminium pasta sebagai bahan pengisi udara kimiawi dan pengeras beton.
Analisis material dinding hebe diuraikan pada tabel berikut ini:

Tabel IV.13 Analisis Material dinding pada bangunan IKM

\begin{tabular}{|c|c|c|}
\hline Analisis & Bata Ringan & Kaca \\
\hline Bahan & $\begin{array}{l}\text { Pasir kwarsa, } \\
\text { semen kapur, } \\
\text { gypsum, air dan } \\
\text { aluminium pasta }\end{array}$ & Kaca, perekat \\
\hline ukuran & $60 \times 20 \times 10 \mathrm{~cm}$ & - \\
\hline Berat & $1 \mathrm{~kg} \mathrm{~kg} / \mathrm{buah}$ & - \\
\hline Perekat & $\begin{array}{l}\text { Semen instan } \\
11,43 \text { kg : air } \\
0,15\end{array}$ & Karet perekat \\
\hline $\begin{array}{l}\text { Area } \\
\text { aplikasi }\end{array}$ & $\pm 8 \mathrm{buah} / \mathrm{m}^{2}$ & - \\
\hline $\begin{array}{l}\text { Kelebih } \\
\text { an }\end{array}$ & $\begin{array}{l}\text { Kedap air, } \\
\text { pemasangan } \\
\text { cepat, ringan, } \\
\text { tahan api, kedap } \\
\text { suara, tidak perlu } \\
\text { diplester, } \\
\text { dinding pengisi } \\
9-12 \mathrm{~m}^{2}\end{array}$ & $\begin{array}{l}\text { Kedap air, } \\
\text { pemasangan } \\
\text { cepat, ringan, } \\
\text { tahan api, } \\
\text { kedap suara, }\end{array}$ \\
\hline $\begin{array}{l}\text { kekuran } \\
\text { gan }\end{array}$ & $\begin{array}{l}\text { Harga lebih } \\
\text { mahal }\end{array}$ & $\begin{array}{l}\text { Harga reltatif } \\
\text { mahal }\end{array}$ \\
\hline $\begin{array}{l}\text { Penerap } \\
\text { an pada } \\
\text { desain }\end{array}$ & $\begin{array}{l}\text { Material dinding } \\
\text { ini lebih baik } \\
\text { digunakan pada } \\
\text { bangunan IKM, } \\
\text { pemasangan } \\
\text { yang mudah dan } \\
\text { ccepat serta daya } \\
\text { tahan merupakan } \\
\text { keunggulan } \\
\text { material ini jika } \\
\text { dipasang pada } \\
\text { bangunan. }\end{array}$ & $\begin{array}{l}\text { Material ini } \\
\text { digunakan } \\
\text { dibeberapa } \\
\text { bangunan } \\
\text { IKM seperti } \\
\text { pada atrium } \\
\text { pada gedung } \\
\text { perkuliahan }\end{array}$ \\
\hline
\end{tabular}

Sumber: Analisis Penulis, 2012

Kaca adalah amorf (non kritalin) material padat yang bening dan transparan (tembus pandang), Kaca dibuat dari campuran $75 \%$ silikon dioksida $(\mathrm{SiO} 2)$ plus $\mathrm{Na} 2 \mathrm{O}, \mathrm{CaO}$, dan beberapa zat tambahan. Suhu lelehnya 
$\begin{array}{lccc}\text { adalah } & 2.000 & \text { derajat Celsius. } \\ \text { (http://id wikipedia org/ wiki/Kaca) }\end{array}$

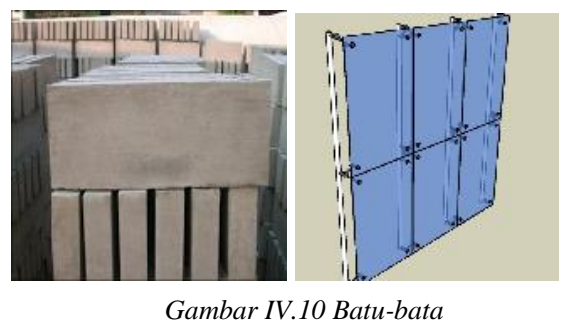

(Sumber:http://blog.ub.ac.id/, diakses 18/12/2012

\section{Material Lantai}

Lantai merupakan material pembentuk suatu ruang. Bangunan IKM memerlukan material lantai yang dapat mewadahi fungsi masing-masing jenis ruang. Adapun jenis-jenis lantai adalah sebagai berikut:

Lantai kayu, penggunaan Kayu yang fleksibel dapat memberikan suasana elegan, klasik, modern maupun kontemporer; Lantai marmer dan granit, merupakan bahan tambang yang langsung diambil dari alam. Pengolahannya hanya memerlukaan proses pemotongan dan penghalusana. Lantai granit pada prinsipnya hampir sama dengan marmer, hanya secara kasat mata warnanya lebih gelap. Lantai Keramik memiliki motif warna dan ukuran keramik pun sangat beragam dari motif marmer, polos, serat kayu dan masih banyak lagi. Lantai Vinyl ini sangat praktis untuk mengubah tampilan ruangan. Material ini sangat kuat, tahan api dan air .

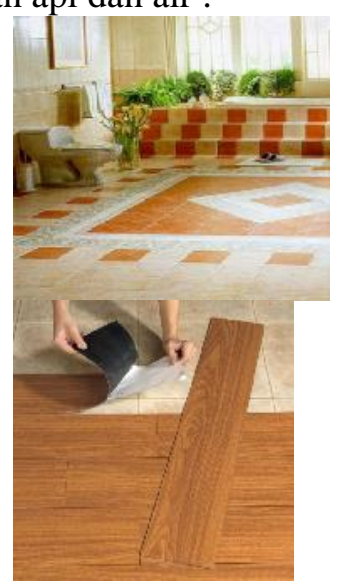

Gambar IV.14 Lantai keramik bertekstur (Sumber:http://old.kaskus.co.id/showthread.php?t=76 83882\&page $=2$ diakses $18 / 12 / 2012$ )

\section{Material Plafond}

Plafond atau langit-langit merupakan bidang pembatas antara atap dan ruangan di bawahnya. Ketinggian plafond atau langit-langit umumnya berkisar antara 2,75 s/d 3,75m. Plafond yang digunakan pada banguan IKM adalah ; Gypsum board, Ukuran untuk plafond gypsum adalah 122 $\mathrm{cm} \times 244 \mathrm{~cm}$. Untuk rangka seperti GRC Board anda dapat menggunakan kaso maupun besi hollow 4/4 dan 4/2.

Akustik Board, merupakan plafond yang dapat meredam kebisingan. Karena plafond akustik merupakan plafond yang tahan terhadap batas ambang kebisingan tertentu. Ukuran yang tersedia adalah 60 $\mathrm{cm}$ x $60 \mathrm{~cm}$ dan $60 \mathrm{~cm}$ x $120 \mathrm{~cm}$.

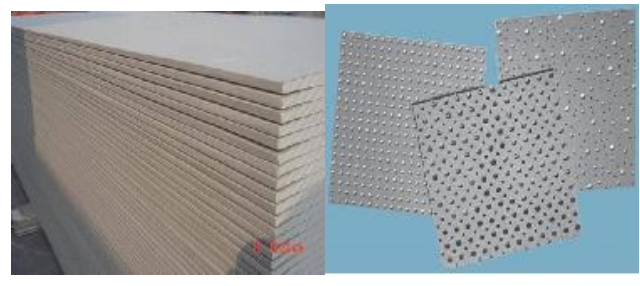

Gambar IV.16 Gypsum untuk plafond

(Sumber:http://emivomarket.com/diakses 19/12/2012)

Analisis material plafond yang akan digunakan pada bangunan IKM

bangunan IKM. Sumber daya yang utama dalam bangunan adalah dari :

\section{Perusahaan Listrik Negara (PLN)}

Digunakan untuk melayani kebutuhan listrik seluruh kegiatan bangunan. Untuk distribusi jaringan ke dalam tapak sebaiknya dilakukan melalui jaringan bawah tanah sehingga tidak mengganggu visual maupun kegiatan yang ada.

\section{Generator}

Digunakan sebagai cadangan yang bekerja secara otomatis apabila aliran listrik dari PLN putus. Sumber daya ini digunakan untuk melayani bagian-bagian penting yang menggunakan daya listrik yaitu sebagian dari penerangan bangunan, pompa-pompa, exhaust fan, lift dan escalator serta hidrant peletakan dari generator ini dipertimbangkan terhadap 
kebisingan yang terjadi serta kemudahan pemeliharaan.

\section{Sistem plumbing}

Sistem plumbing terdiri atas :

\section{Air bersih}

Sumber air berasal dari PDAM, sedangkan untuk kebutuhan service seperti pemeliharaan bangunan, penyiraman tanaman dan pompa / dep well.

Sistem distribusi air yang digunakan adalah dengan sistem down feed distribution, yaitu ditampung pada reservoir bawah. Setelah itu air di pompa naik ke reservoir atas dan selanjutnya didistribusikan dengan memanfaatkan gaya grafitasi. Dengan sistem ini air bersih akan tetap mengalir meskipun aliran listrik terputus.

\section{Sistem pembuangan air kotor}

Terdiri atas; air hujan dan air kotor yang berasal dari bangunan dialirkan langsung ke riol kota . Air kotor yang berasal dari WC dialirkan melalui saluran khusus ke bak penampung

\section{Sampah}

Dalam suatu sistem bangunan komersial, kebersihan merupakan faktor yang sangat penting, karena itu sistem pembuangan sampah harus diperhatikan dengan baik dan tidak mengganggu kegiatan yang terjadi. Pembuangan sampah secara vertikal dilakukan melalui sharf, sampah-sampah ini ditampung dalam bak sampah untuk kemudian diangkut ke luar tapak.

\section{Sistem komunikasi dan tata suara}

Penentuan sistem komunikasi dan tata suara yang digunakan dipertimbangkan terhadap :

Tingkat kebutuhan masing-masing kegiatan, Kemudahan dan kelancaran komunikasPengolahan bangunan Sistem komunikasi yang digunakan dalam bangunan berupa; Intercom, yang digunakan untuk menghubungkan antar ruang dalam bangunan., PABX (Privat Automatic Branch Exchange) yaitu sistem sambungan menghubungkan keluar tanpa operator., Facsimile, yaitu untuk menyampaikan data secara tertulis, Telex, yaitu sistem nomor atau saluran pribadi, Telepon umum, yang digunakan untuk melayani kebutuhan pengunjung, Selain itu diperlukan pula sistem tata surya yang dipergunakan untuk keperluan pengumuman, promosi dan panggilan.

\section{Sistem pencegahan kebakaran}

Bahaya kebakaran merupakan hal yang perlu dihindari, pencegahan terhadap bahaya kebakaran dilakukan dengan menyediakan sarana pencegahan kebakaran yang memadai dan berfungsi dengan baik serta kesiagaan terhadap kemungkinan kebakaran yang terjadi.

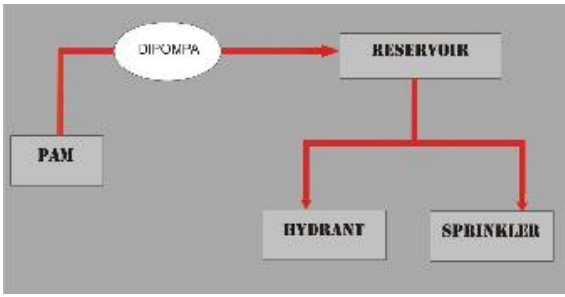

Gambar IV.21 Skema penanggulangan bahaya kebakaran dalam IKM

(Sumber:dokumen pribadi, 2013)

\section{Sistem transportasi vertikal}

Karena bangunan ini merupakan bangunan bertingkat, maka untuk kelancaran sirkulasi diperlukan adanya peralatan sirkulasi vertikal dalam bangunan, berupa; Tangga, digunakan pada tempat-tempat umum seperti pada hall utama, service dan darurat; Escalator, digunakan untuk sirkulasi pengunjung sehingga harus diletakkan pada area yang terlihat langsung; Evalator, digunakan untuk umum dan juga untuk barang dan service.

\section{Sistem keamanan \\ Sistem penangkal petir}

Sistem penangkal petir digunakan pada bangunan untuk melindungi dari bahaya ledakan dan kebakaran yang ditimbulkan oleh sambaran petir. Pemilihan sistem penangkalan petir dipertimbangkan terhadap ketinggian bangunan dan segi 
estetika, utamanya pada penampilan bangunan dan pemeliharaan. Sistem penangkalan petir yang digunakan pada IKM adalah sistem Faraday, yang terdiri dari; Alat penerima setinggi $150 \mathrm{~cm}$ pada setiap jarak 20 meter, kawat mendatar,

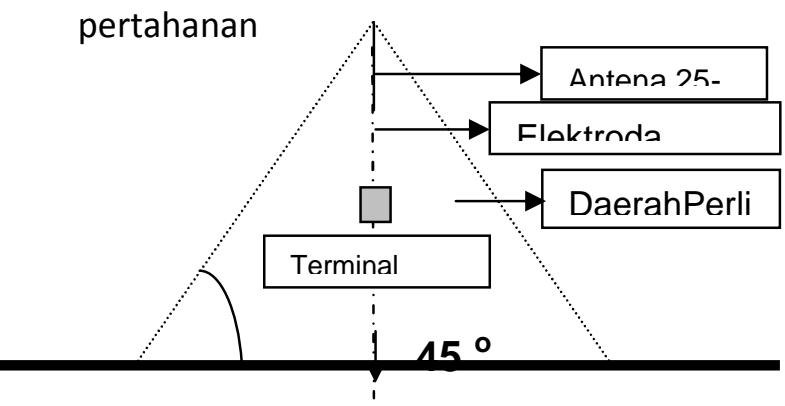

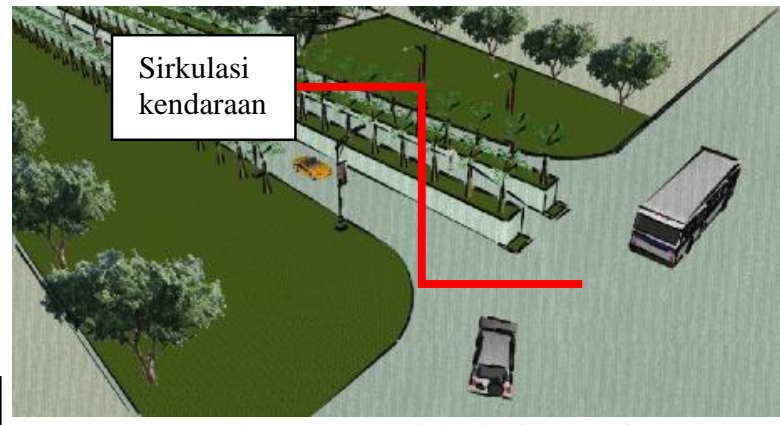

Gambar IV.23 Sirkulasi menuju tapak

(Sumber:dokumen pribadi, 2013)

Parkir

Berikut pengendalian area parker yang

Gambar IV.22 Skema penangkal petir dalam IKM, (Sumber:dokumen pribadi, 2013)

Keamanan terhadap bahaya kriminal

Sistem pencegahan dan penanggulangan terhadap bahaya kriminalitas dilakukan dengan; sistem CCTV dengan kamera yang memantau daerah-daerah yang sering dilalui pengunjung, sistem alarm yang dapat dibunyikan apabila ada kejadian yang mencurigakan.

\section{Sirkulasi}

Dalam perancangan IKM, sirkulasi merupakan hal yang paling penting untuk diperhatikan. Sirkulasi yang ada berupa sirkulasi manusia, kendaraan dan barang. Dengan demikian, objek rancangan diharapkan mampu untuk mewadahi berbagai aktifitas di dalam IKM dengan baik.

\section{Sirkulasi Makro}

Berikut beberapa sirkulasi yang mendukung perancangan IKM, diantaranya: Entrance ,jalan dan pedestrian. mendukung perancangan IKM:

Perbedaan area parkir Mahasiswa, pengelola dan pengunjung dengan maksud agar tidak terjadi keruwetan dan kemacetan pada area parkir. Dengan demikian akan memepermudah akses menuju bangunan. Selain itu juga untuk membedakan tingkat privasi. Penggunaan sistem cross sirculationdan penataan area parkir dengan sistem searah pada area parkir, dengan maksud untuk mempermudah kendaraan keluar-masuk. Dengan demikian, tidak terjadi kemacetan dan keruwetan pada area parkir.

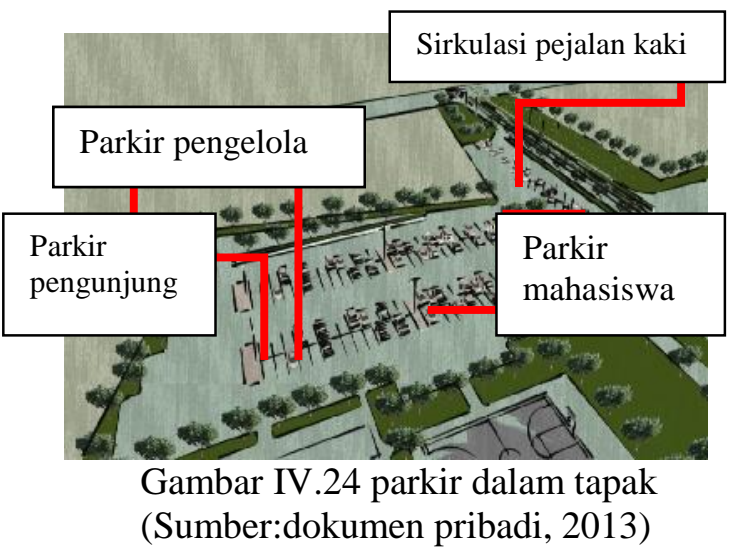

\section{Sirkulasi Mikro}

Sistem sirkulasi horisontal merupakan merupakan jalan lalu-lalang antar ruang dalam satu lantai. Persentase kemiringan pada sirkulasi jenis ini tidak lebih dari $10 \%$, yang termasuk transportasi jenis ini adalah koridor dan konveyor. (Poerbo, 
1992 Sirkulasi horisontal pada bangunan IKM berupa koridor yang menghubungkan antar ruang yang satu dengan ruang yang lainnya dalam lantai yang sama.

Sistem Sirkulasi vertikal pada bangunan IKM menghubungkan antara lantai yang satu dengan lantai yang lainnya. Jenis sirkulasi yang digunakan adalah berupa tangga dan lift.

\section{APLIKASI DESAIN}

Desain Site

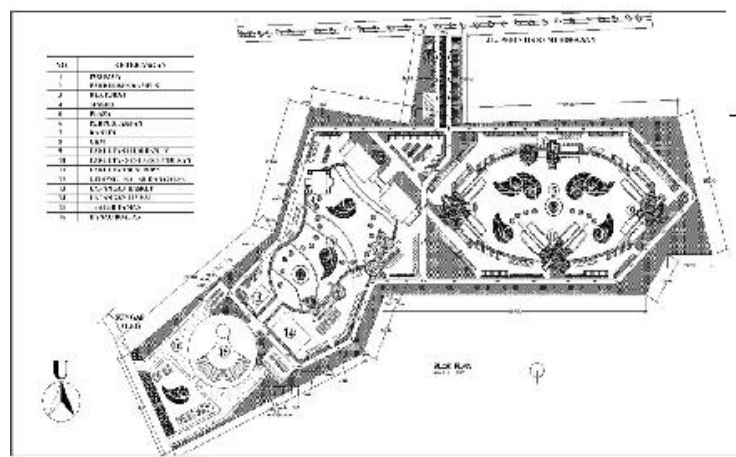

Gambar IVb.1 Site plan

(Data pribadi, 2013)

Denah, Tampak,Potongan Bangunan

Fakultas seni film

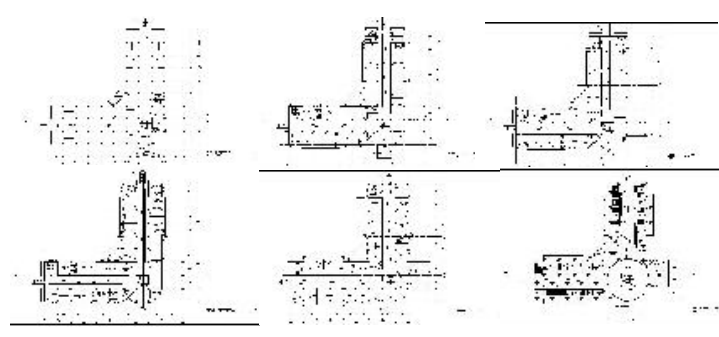

Gambar IVb..2.Denahbangunanfakultasseni film

(Data pribadi, 2013)
Fakultas seni pertunjukan

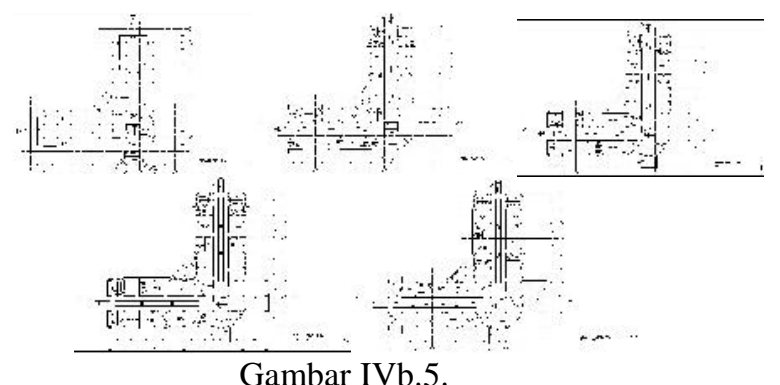

Denahbangunanfakultassenipertunjukan

(Data pribadi, 2013)

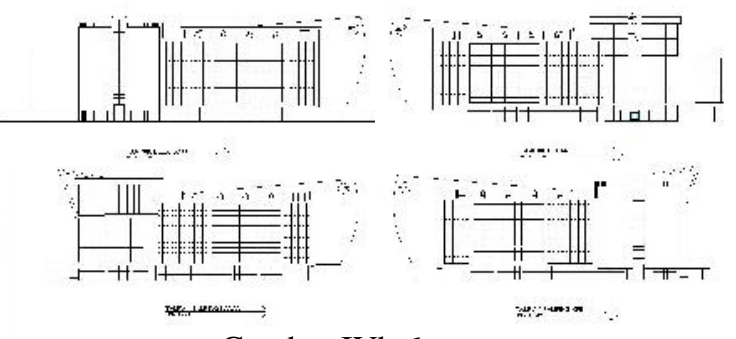

Gambar IVb.6.

Tampakbangunanfakultassenipertunjukan (Data pribadi, 2013)

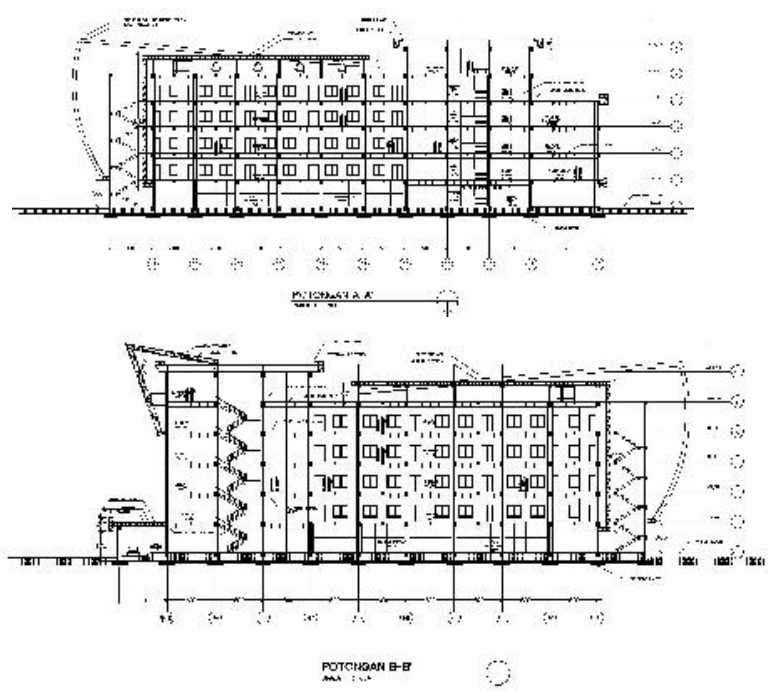

Gambar IVb.7.

Potonganbangunanfakultassenipertunjukan

(Data pribadi, 2013) 
Fakultas senirupa

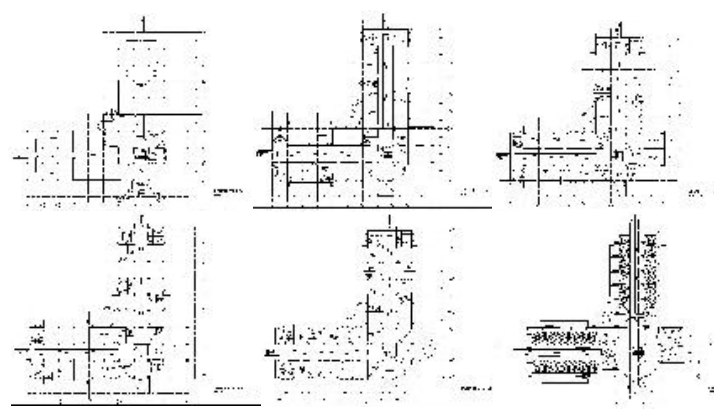

Gambar IVb..8.

Denahbangunanfakultassenirupa

(Data pribadi, 2013)

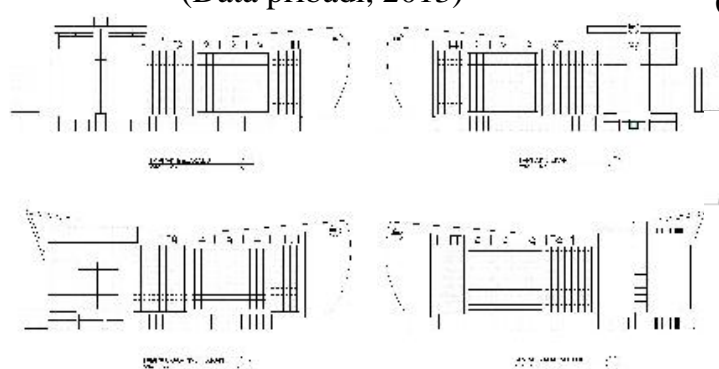

Gambar IVb .9.

Tampakbangunanfakultassenirupa (Data pribadi, 2013)
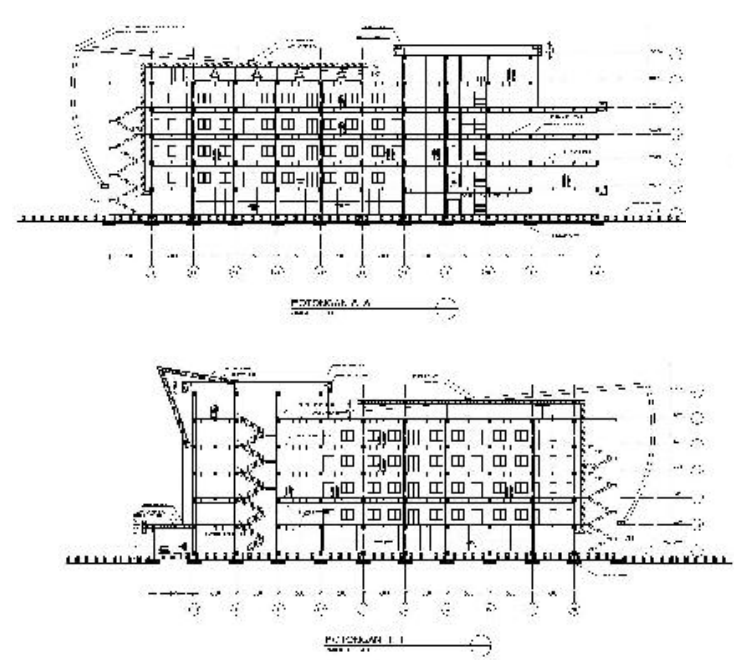

Gambar IV.10. Potongan bangunan fakultas seni rupa, (Data pribadi, 2013)

\section{Gedung Galeri}

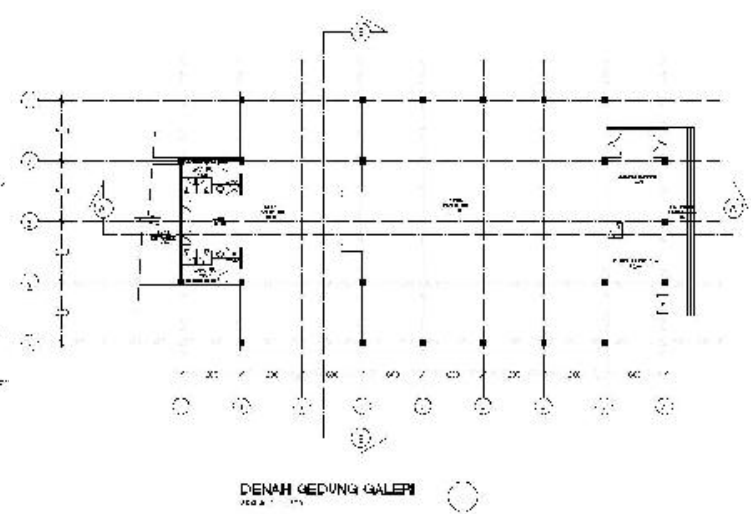

Gambar IVb.11. Denahbangunangedunggaleri (Data pribadi, 2013)
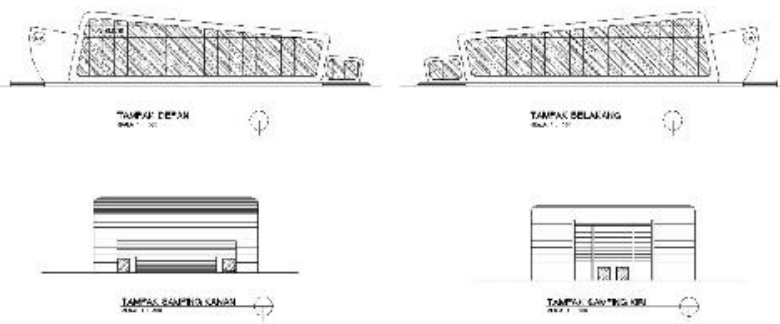

Gambar IVb.12. Tampak bangunan gedung galeri, (Data pribadi, 2013)

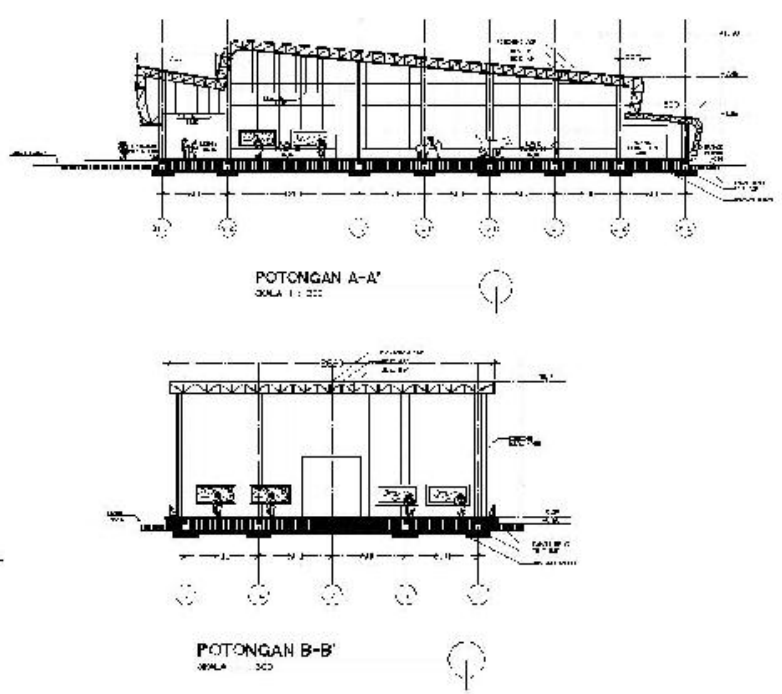

Gambar IVb.13. Potongan gedung galeri

(Data pribadi, 2013) 


\section{GedungTeater}

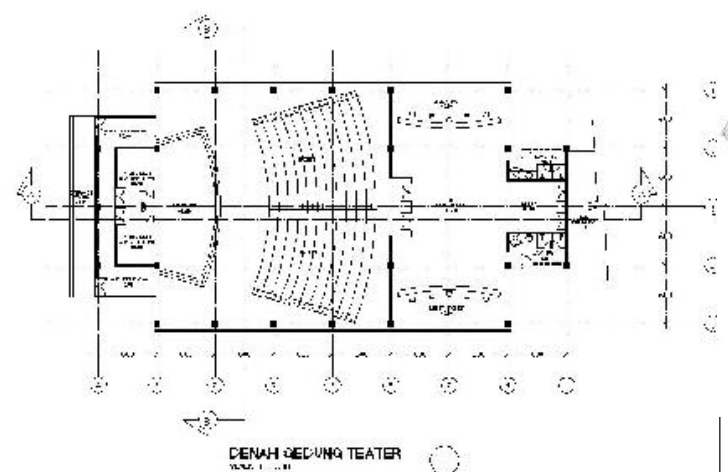

Gambar IVb.14. Denahbangunangedungteater

(Data pribadi, 2013)

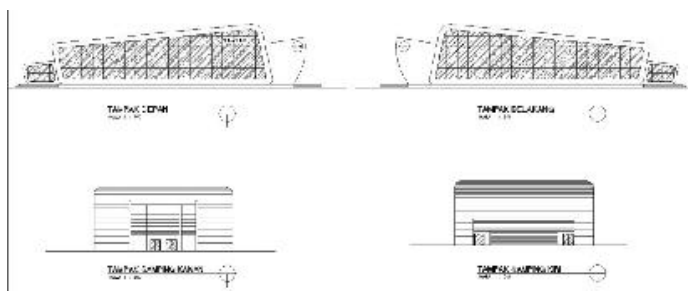

Gambar IVb.15. Tampakbangunangedungteater (Data pribadi, 2013)

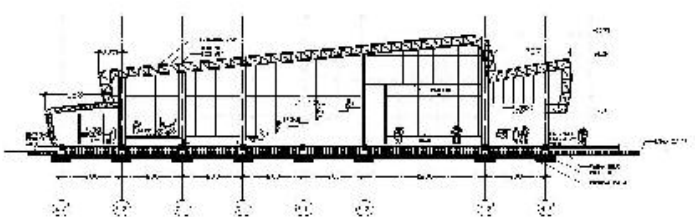

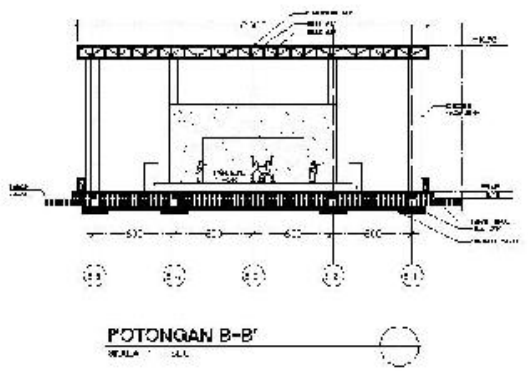

Gambar IVb.16. Potongan gedung teater (Data pribadi, 2013)

Masjid

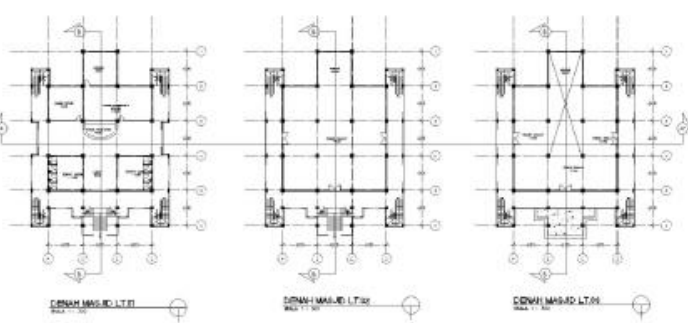

Gambar IVb.17. Denah masjid (Data pribadi, 2013)

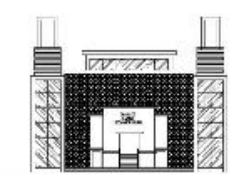

Tampar Cerow

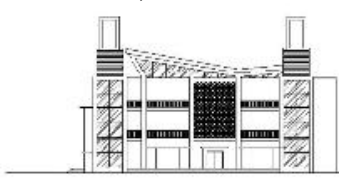

TRAPAK S KANWAL
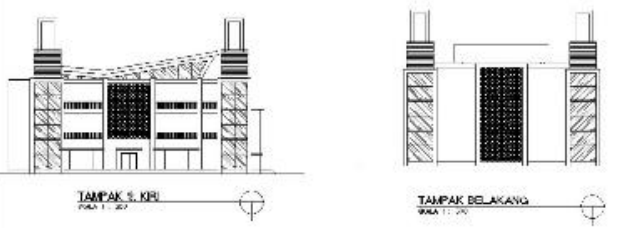

Gambar IVb.18. Tampak masjid (Data pribadi, 2013)

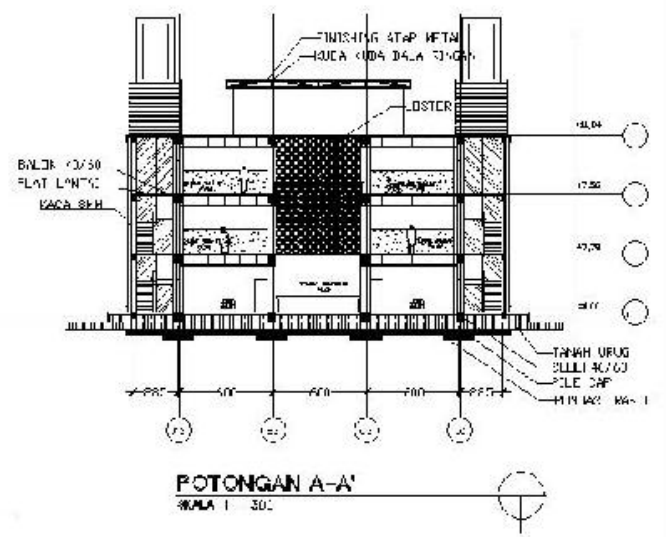

Gambar IVb.19. Potongan masjid (Data pribadi, 2013) 
Nature

\section{Gedung Rektorat}

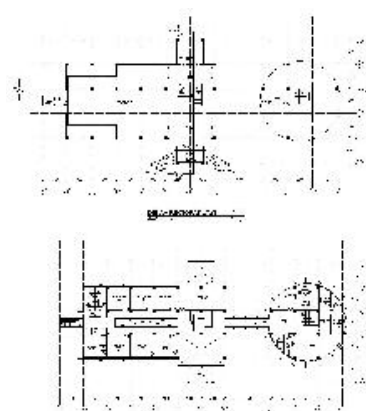

acesicis
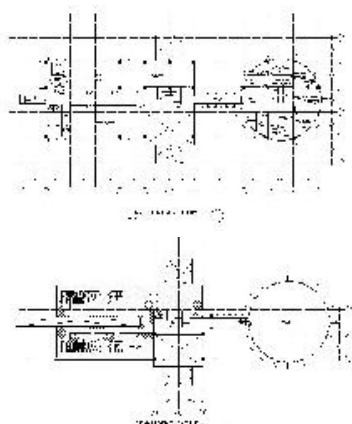

Gambar IVb.20. Denahgedungrektorat (Data pribadi, 2013)

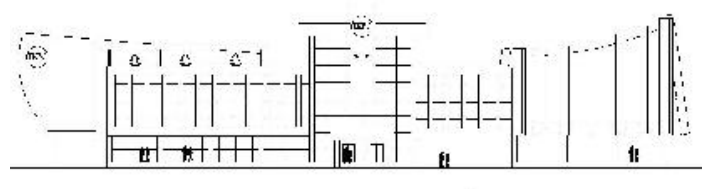
TALFA: : C.FAN

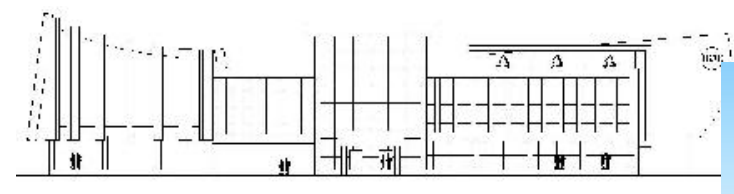

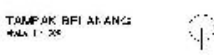
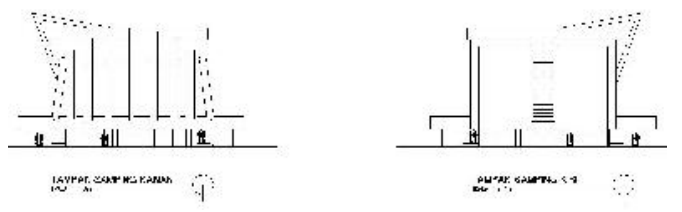

Gambar IVb.21. Tampakgedungrektorat

(Data pribadi, 2013)

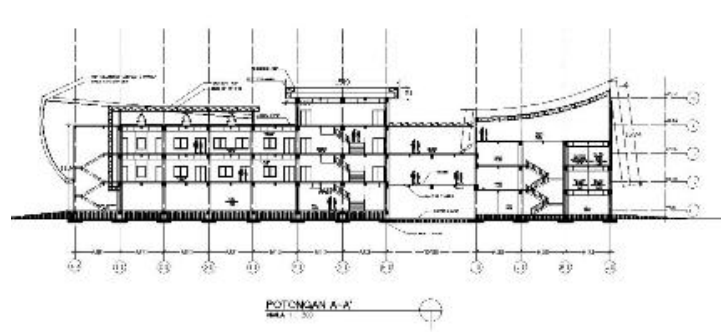

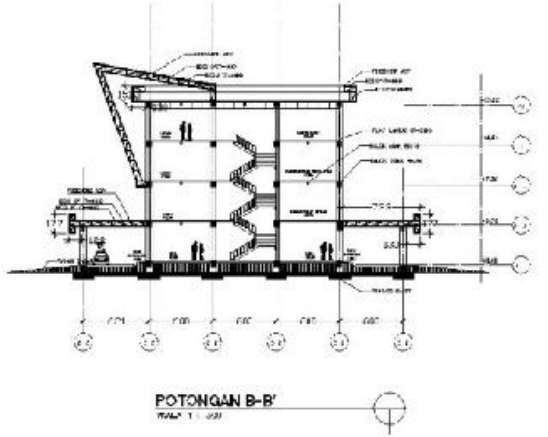

Gambar IVb.22. Potongan gedung rektorat (Data pribadi, 2013)

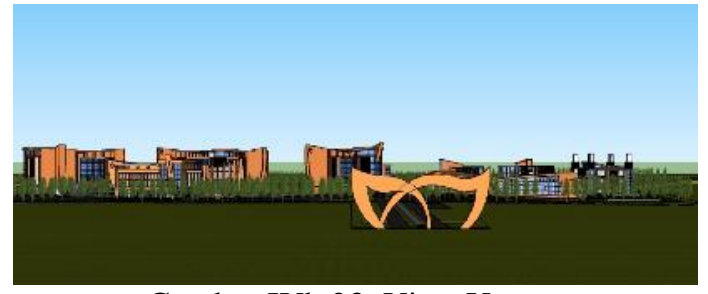

Gambar IVb.23. View Utara

(Data pribadi, 2013)

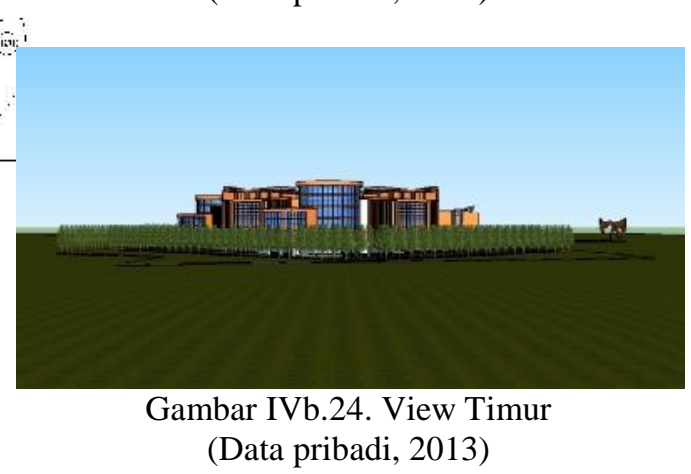

(Data pribadi, 2013)

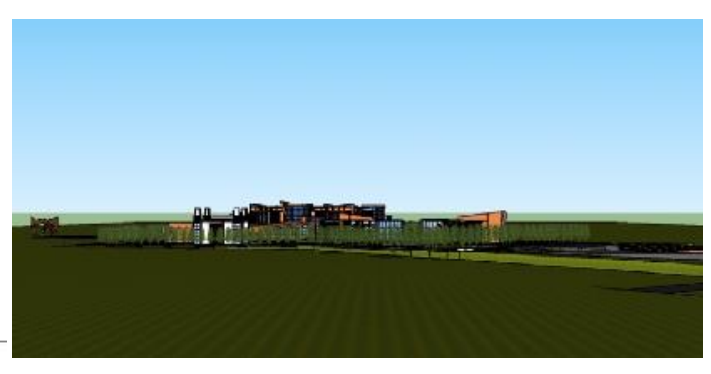

Gambar IVbI.24. View Barat

(Data pribadi, 2013) 


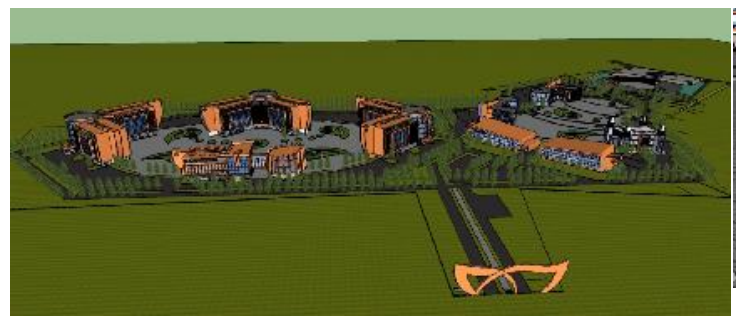

Gambar IVb.27. Perspektif Mata Burung

(Data pribadi, 2013)

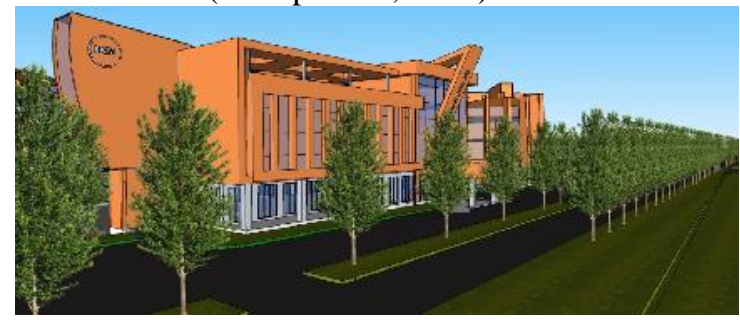

Gambar IVb.28. PerspektifRektorat (Data pribadi, 2013)

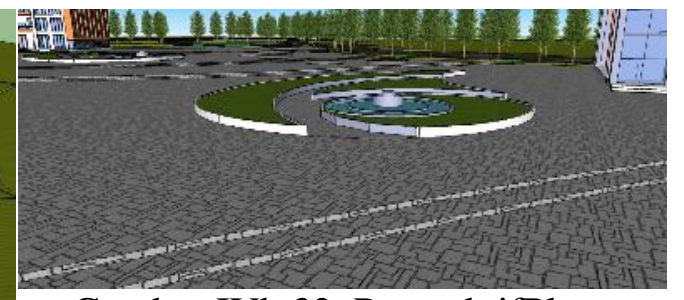

Gambar IVb.32. PerspektifPlaza (Data pribadi, 2013)

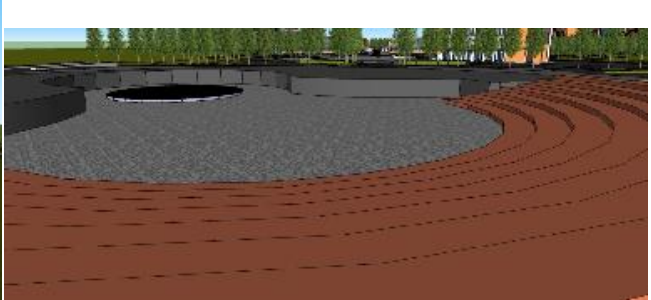

Gbr. IVb.33. PerspektifTeaterLapangan (Data pribadi, 2013)

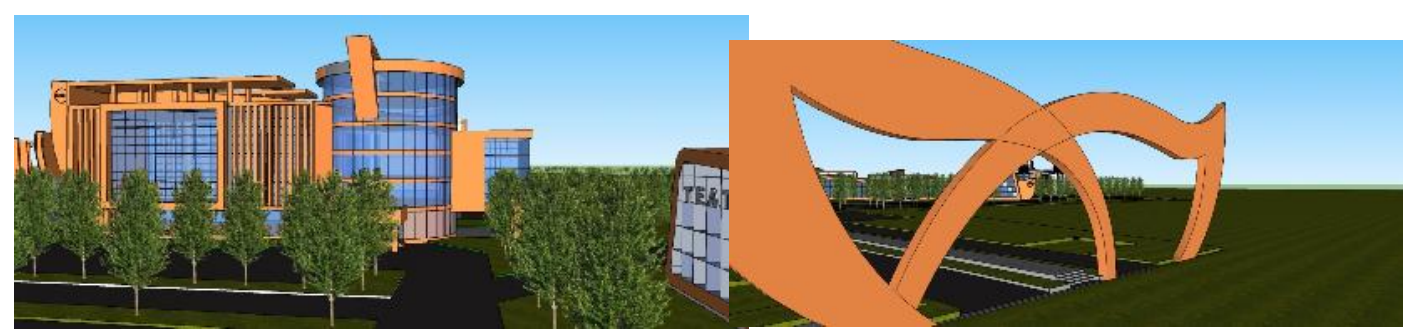

Gambar IVb.29. Perspektif Fakultas (Data pribadi, 2013)

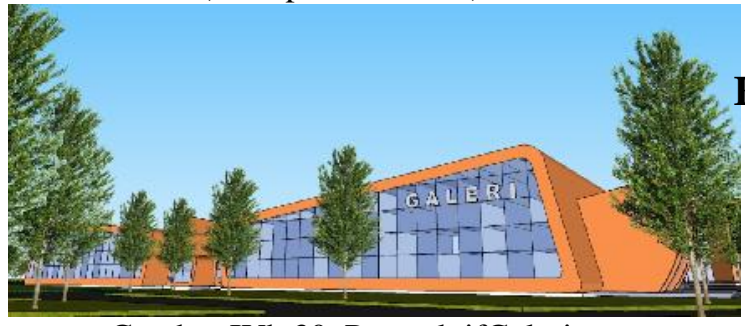

Gambar IVb.30. PerspektifGaleri (Data pribadi, 2013)

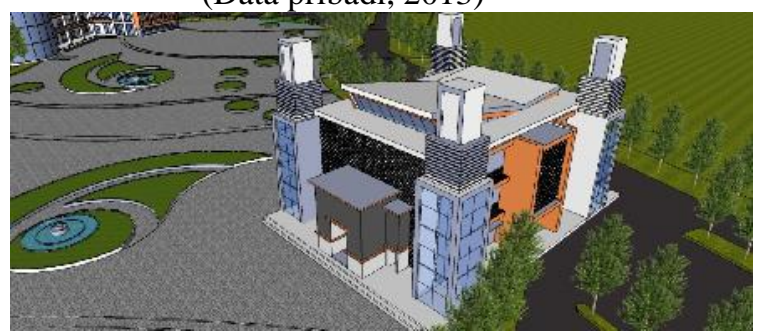

Gbr. IVb.34. PerspektifGerbang

(Data pribadi, 2013)

\section{Foto Maket}

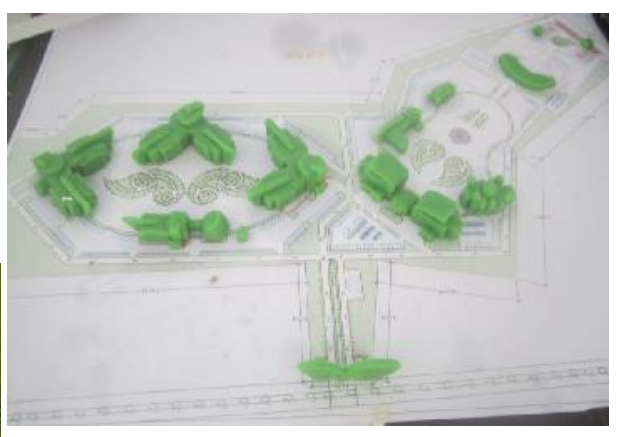

Gambar IVb.35.

Studibentukdenganbahanplastisin (Data pribadi, 2013)

Gambar IVb.31. PerspektifMasjid

(Data pribadi, 2013) 
Nature

National Academic Journal of Architecture

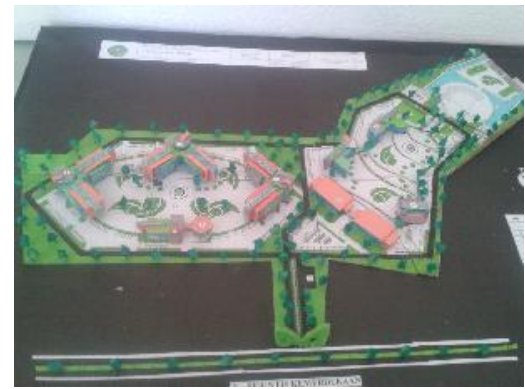

Gambar IVb.36. Maket

(Data pribadi, 2013)

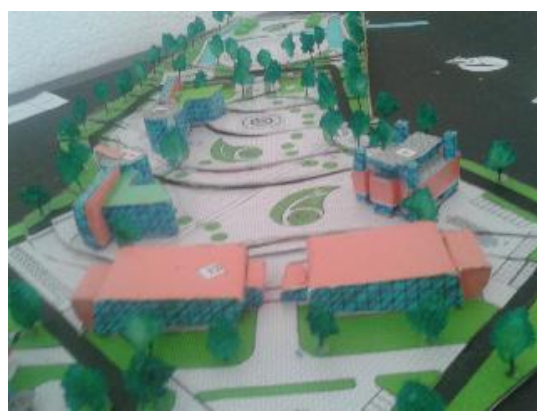

Gambar III.37. Maket

(Data pribadi, 2013)

\section{KESIMPULAN}

Perancang sebuah Institut Kesenian yang berlokasi di Makassar yang dapat mewadahi

kebutuhan seniman untuk menyalurkan dan mengembangkan kreativitasnya, serta dapat menghasilkan lulusan yang memiliki kepekaan terhadap nilai-nilai seni dan budaya bangsa, terampil dan kreatif sebagai seniman. Dengan perencanaan dan perancangan yang tepat maka bangunan ini dapat mewadahi sesuai dengan peruntukannya sebagai gedung Institut kesenian. Hal ini pula dapat dijadikan rekomendasi atau usulan kepada pemerintah dan para pemerhati, sehingga bangunan ini dapat mewadahi mahasiswa dalam menyalurkan, mengembangkan kreatifitas dan pemberian fasilitas yang dapat mengakomodir pengembangan dan pelestarian seni budaya setempat menurut kebutuhan pengguna yang sesuai standar.

\section{DAFTAR PUSTAKA}

Arini, Sri Hermawanti Dwi. Seni Budaya Jilid 1. Jakarta : Direktorat Pembinaan Sekolah Menengah Kejuruan, 2008

Arini, Sri Hermawanti Dwi. Seni Budaya Jilid 2. Jakarta : Direktorat Pembinaan Sekolah Menengah Kejuruan, 2008

Depdiknas. Kamus Besar Bahasa Indonesia. Jakarta: Balai Pustaka, 2008

Margono, Tri Edy. Mari Belajar Seni Rupa. Jakarta: Pusat Perbukuan Kementrian Pendidikan Nasional, 2010

M. Quraish Shihab. Tafsir Al-Misbah, Jakarta: Lentera Hati, 2002

Mutaqin, Moh. Seni Musik Klasik. Jakarta Direktorat Pembinaan Sekolah Menengah Kejuruan, 2008

Badan Pusat Statistik Kota Makassar.Makassar Dalam Angka 2011.Ud Areso:Makassar, 2011

Lechner, Norbert. Heating, Cooling, Lighting. Jakarta: PT Raja Grafindo Persada, 2001

Marlina, Endy. Panduan Perancangan Bangunan Komersial.Penerbit Andi:Jakarta, 2008

Neufert, Ernest. Data ArsitekJilid 1. Erlangga: Jakarta, 1997

Neufert, Ernest. Data ArsitekJilid II. Erlangga: Jakarta, 2002

Harris, Charles W dan Nicholas T Dines.Times Server Standards for landscape architecture.Mc-Graw-Hill Publishing Company: United State, 1998

Panero, Julius dan Martin Zelnik. .Dimensi Manusia dan Ruang Interior

Noerbambang, Sofyan M. Dan Takeo Morimura.Perencanaan dan Pemeliharaan Sistem Plambing.PT Pradnya Paramita : Jakarta, 1991

Satwiko, Prasatyo. Fisika Bangunan 2, Edisi 1.Penerbit Ansi:Yogyakarta, 2004

Hakim, Rumam dan Hardi Utomo. Komponen Perancangan Arsitektur Lansekap.PT Bumi Aksara:Jakarta, 2008

Frick, Heinz dan Bambang Suskiyanto. DasarDasar Arsitektur Ekologis.Kansius: Yogyakarta, 2007

Allen, Edward. Dasar-Dasar Konstruksi Bangunan, Bahan-Bahan dan Metodenya jilid 1.Erlangga: Jakarta, 2003

Poerbo, Hartono.Utilitas Bangunan. Djambatan:Jakarta, 1992 
Situs Internet:Wikipedia. 2012. Institut (OnLine).http://id.wikipedia.com/wiki/instit ut, diakses 21/09/2012

Wikipedia. 2012. Kota Makassar (On-Line). http://id.wikipedia.com/wiki/KotaMakassar, diakses 21/09/2012

Institut Seni Indonesia Yogyakarta. Profil (OnLine). http://isi.ac.id/profil/ diakses 02/10/2012

Anonim. School of art Design and Media (OnLine). http://www.architecturelist.com, diakses 10 Oktober 2012 
Nature

National Academic Journal of Architecture 